\section{MODELY CIRKULACE A PŘENOSU KREVNÍCH PLYNŮ PRO LÉKAŘSKOU VÝUKU}

\section{Jiří Kofránek, Martin Tribula, Pavol Privitzer}

\section{Anotace}

Výukové modely cirkulace a přenosu krevních plynů umožňují názorně demonstrovat dynamické propojení regulačních smyček a jejich projevy při nejrůznějších patogenezích poruch kardiorespiračního systému. Jejich nasazení ve výuce mediků prokázalo jejich vysokou pedagogickou účinnost.

\section{Klíčová slova}

simulace, simulátor, výuka, modely, cirkulace, přenos krevních plynů

\section{1 Úvod - simulační hry pro výuku medicíny}

Simulační modely jsou ve výuce medicíny účinnou výukovou pomůckou, která umožní názorně pomocí simulační hry s modelem vysvětlit dynamické souvislosti regulace fyziologických dějů v normě i v patologii, a přispět tak k pochopení patogeneze rady chorob. Častým objektem pro výukové modely v medicíně je cirkulační systém. Již koncem 70. let Guyton využíval ve výuce budoucích lékařủ svůj klasický integrativní model návazností cirkulačního systému [1] a Coleman v roce 1983 tento model rozšíril speciálně pro potřeby výuky nejen cirkulačního systému a pod názvem HUMAN jej nabízel ve formě zdrojového textu ve Fortranu [2]. Speciálně pro výukové účely byl potom vyvinut rozsáhlý integrativní model pod názvem Quantitative Circulatory Physiology (QCP), [3], který byl základem současného nejrozsáhlejšího modelu lidské fyziologie HumMod [4-13] (www. hummod.org). V současné době autoři HumModu vyvinuli (placenou) nadstavbu pro využití tohoto rozsáhlého modelu ve výuce s názvem „Just Physiology“ (http://justphysiology.com).

Spojení internetu a interaktivního multimediálního prostředí se simulačními modely přináší zcela nové pedagogické možnosti zejména pro vysvětlování složitě provázaných vztahů, pro aktivní procvičování praktických dovedností a pro ověřování teoretických znalostí. V zapojení multimediálních výukových her do výuky nachází své moderní uplatnění staré krédo Jana Amose Komenského „Schola Ludus“ - tj. „škola hrou“ [14], které tento evropský pedagog razil již v 17. století.

Simulační hry pro výuku medicíny jsou součástí nabídky řady komerčních firem. Vedle komerčních simulátorů Ize na internetu najít i volně dostupné výukové simulátory jednotlivých fyziologických subsystémů. Jedním z výsledků našeho úsilí v této oblasti je internetový Atlas fyziologie a patofyziologie [1517], koncipovaný jako volně dostupná multimediální výuková pomůcka, která názornou cestou, prostřednictvím internetu, s využitím simulačních modelů vysvětluje funkci jednotlivých fyziologických systémů i příčiny a projevy jejich poruch (http:// physiome.cz/atlas).

\section{Od modelů cirkulace ve Fortranu k webovým simulá- torům pro lékařskou výuku}

Kdysi se simulační modely vytvářely v klasických programovacích jazycích jako je např. Fortan, $\mathrm{C}++$ a další. Ve Fotranu byl implementován výše zmíněný klasický Guytonův model cirkulačního systému [1], ve Fortranu byl napsán i výukový model HUMAN Thomase Colemana [2].

Počátkem devadesátých let se objevily blokově orientované simulační nástroje (např. Simulink od firmy Mathworks), kde se modely pomocí počítačové myši v grafickém editoru postupně skládaly pomocí propojování jednotlivých výpočetních bloků. V propojkách mezi jednotlivými bloky „tečou“ signály, které přenášejí hodnoty jednotlivých proměnných od výstupu jednoho bloku ke vstupům dalších bloků. V blocích dochází ke zpraco- vání vstupních informací na výstupní. Z propojení jednotlivých bloků je pak zřejmé, jakým způsobem se počítají hodnoty jednotlivých proměnných - tj. jaký je algoritmus výpočtu.

Bloky je možné seskupovat do jednotlivých subsystémů, které se svým okolím komunikují prostřednictvím vstupních a výstupních „pinư" a představují tak jakési, „simulační čipy“. Tyto subsystémové bloky ukrývají před uživatelem strukturu simulační sítě, obdobně jako elektronický čip ukrývá před uživatelem strukturu propojení jednotlivých tranzistorů a dalších elektronických prvků, a uživatel se nemusí starat o vnitřní strukturu a algoritmus výpočtu výstupních proměnných ze vstupních. "Simulační čipy" v blokově orientovaných jazycích mají hierarchickou strukturu - obsahem může být sít propojených subsystémových bloků nižší hierarchické úrovně.

Blokově orientované simulační jazyky podstatně usnadnily implementaci simulačních modelů. Hlavní potíž blokově orientovaných jazyků však tkví v tom, že simulační sít složená z hierarchicky propojených bloků zobrazuje grafické vyjádření řetězce transformací vstupních hodnot na výstupní a že při vytváření modelu musíme nadefinovat přesný algoritmus výpočtu od vstupních do výstupních hodnot modelu.

Požadavek pevně zadaného směru spojení od vstupů k výstupům vede $\mathrm{k}$ tomu, že propojení bloků odráží postup výpočtu, a nikoli vlastní strukturu modelované reality.

Na přelomu milénia se objevila zcela nová kategorie modelovacích nástrojů, která umožňuje nestarat se o způsob výpočtu a v modelovacích blocích popisovat prímo rovnice. Byl vytvořen speciální objektově orientovaný jazyk, nazvaný Modelica [18-25]. Modelica, která původně vznikala jako akademický projekt ve spolupráci s malými vývojovými firmami při univerzitách v Lundu a v Linköpingu, se záhy ukázala jako velmi efektivní nástroj pro modelování složitých modelů uplatnitelných zejména ve strojírenství, automobilovém a leteckém průmyslu. Vývoj jazyka Modelica proto postupně získal podporu komerčního sektoru.

Rychlost, s jakou se nový simulační jazyk Modelica rozšíril do různých oblastí průmyslu a jak si Modelicu osvojila nejrůznější komerční vývojová prostředí, je ohromující. Dnes existuje několik komerčních i nekomerčních vývojových nástrojů využívajících tento jazyk (viz https://www.modelica.org).

V simulačním prostředí, využívajícím jazyk Modelica můžeme zapisovat modely prímo pomocí rovnic, a nemusíme tedy implementovat algoritmus řešení rovnic modelu, což podstatně zkracuje časovou náročnost vytváření modelů (viz Obr. 1) [26].

V Modelice je poměrně snadné vytvářet modely cirkulačního systému nejrůznější složitosti - od jednoduchých modelů cirkulačního systému proměnné složitosti $[27,28]$ až velmi komplexní modely integrativní fyziologie [29-31].

Chceme-li však modely využívat pro výuku lékařů, je nutné, aby jejich uživatelské rozhraní připomínalo spíše interaktivní obrázky podobné obrázkům v tištěném atlasu fyziologie a atlasu patofyziologie $[32,33]$ než změt grafů průběžných hodnot fyziologických veličin [16]. Proto se již léta věnujeme vytváření webových výukových simulátorů a rozvoji internetového Atlasu fyziologie a patofyziologie [15-17,34].

Propojení modelů, vytvářených v pohodlí simulačního nástroje pro tvorbu modelů $\mathrm{s}$ webovým simulátorem s interaktivními animovanými obrázky rízenými modelem na pozadí není jednoduché. Proto jsme vypracovali řadu technologií, které nám pomáhají tento problém překlenout [35].

Součástí Atlasu je i výukový webový model krevního oběhu [36]. Model využívá aplikační platformu Microsoft Silverlight. $\checkmark$ pozadí je poměrně sofistikovaná technologie, která umožní propojit model vytvářený v jazyce Modelica s interaktivním uživatelským rozhraním s animovanými obrázky, řizenými (jako loutky) simulačním modelem na pozadí. 


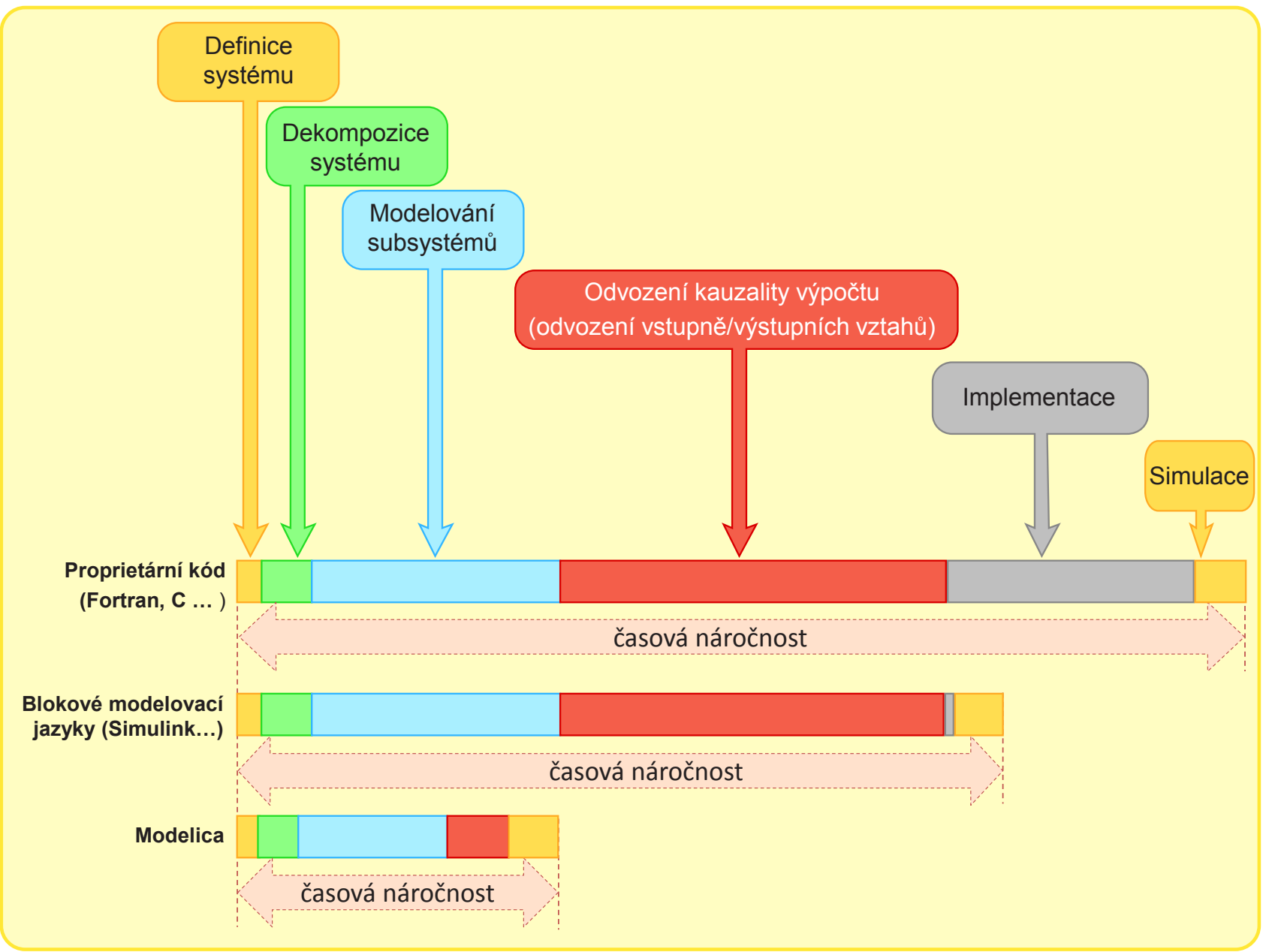

Obrázek 1 - Blokově orientované simulační jazyky přinesly především zkrácení implementace modelu oproti tvorbě modelu v klasických programovacích jazycích. Modelica přinesla dalši časovou úsporu, protože odvození postupu, jak ze vstupních proměnných modelu vypočítávat výstupní, přenechává kompilátoru.

Během posledních let však vyvstal závažný technologický problém - společnost Microsoft uzavřela vývoj aplikační platformy Silverlight, a následně řada webových prohližečů přestala tuto platformu podporovat a naše v ní vytvořené webové simulátory proto nebylo možné spouštět v žádných prohlížečích kromě Microsoft Internet Exploreru.

$\checkmark$ rámci grantového projektu Univerzity Karlovy GAUK č. 198416 byla vytvořena technologie, která dovolila tento problém překlenout. Nyní tedy např. můžeme výukový model krevního oběhu [36] spouštět i mimo platformu Silverlight.

\section{Méně někdy znamená více}

Pro pochopení fyziologických procesů je velmi podstatné chápat návaznosti jednotlivých fyziologických systémů, např́iklad souvislosti cirkulačního systému, regulace objemu a osmolarity, regulace krevních plynů, regulace acidobazické a iontové homeostázy, regulační úlohy respirace a ledvin. To vše spolu úzce souvisí, a právě integrované modely fyziologických systémů mohou dynamické souvislosti mezi těmito fyziologickými subsystémy názorně demonstrovat.

Pro studium cirkulační fyziologie a patofyziologie existuje řada pedagogicky dobře uplatnitelných modelů. Pro výuku fyziologie a patologie EKG se nám ve výuce patofyziologie osvědčil (volně šiřitelný) model holandských autorů [37] ECGSIM (http://www.ecgsim.org). Pro porozumění cirkulační mechanice je vynikajícím nástrojem (volně širitelný) model dalších holandských autorů z Maastrichtu [38] nazvaný CircAdapt (http://www. circadapt.org).
Z didaktického hlediska je nutné při výkladu vždy postupovat od jednoduchého ke složitějšímu. Podle tohoto principu je proto při něm vhodné využívat nejprve jednodušší agregované modely (s několika proměnnými), $s$ jejich pomocí vysvětlit základní principy a poté model (a popisovanou fyziologickou realitu) postupně zesložitovat.

Výukové simulační hry, které jsou součástí našeho internetového Atlasu fyziologie a patofyziologie, nemusí mít vždy podklad ve velmi složitém a výpočetně náročném modelu se stovkami proměnných - $\mathrm{i}$ jednoduchý interaktivní model může být dobrým pomocníkem pro vysvětlení patogenetických řetězců rozvoje nejrůznějších patologických stavů.

Při výkladu fyziologie a patofyziologie oběhu není vhodné začínat simulační hrou s modelem, jehož složitost je zhruba na úrovni modelu HumMod (http://www.hummod.org) se stovkami proměnných.

Naše zkušenosti s lékařskou výukou ukazují, že je zpočátku vhodnější zvolit si jednoduchý agregovaný model, na němž je možné demonstrovat základní principy struktury a chování krevního oběhu a možnosti regulačního ovlivnění.

\section{Webový simulátor krevního oběhu jako výuková pomůcka}

Model cirkulačního systému s rozpojenými regulačními vazbami, který je součástí našeho Atlasu fyziologie a patofyziologie (Obr. 2) je po strukturní stránce co nejjednodušší. Přesto, nebo vlastně právě proto, slouží jako velmi efektivní výuková pomůcka pro vysvětlení základních regulačních vztahů v oběhovém 


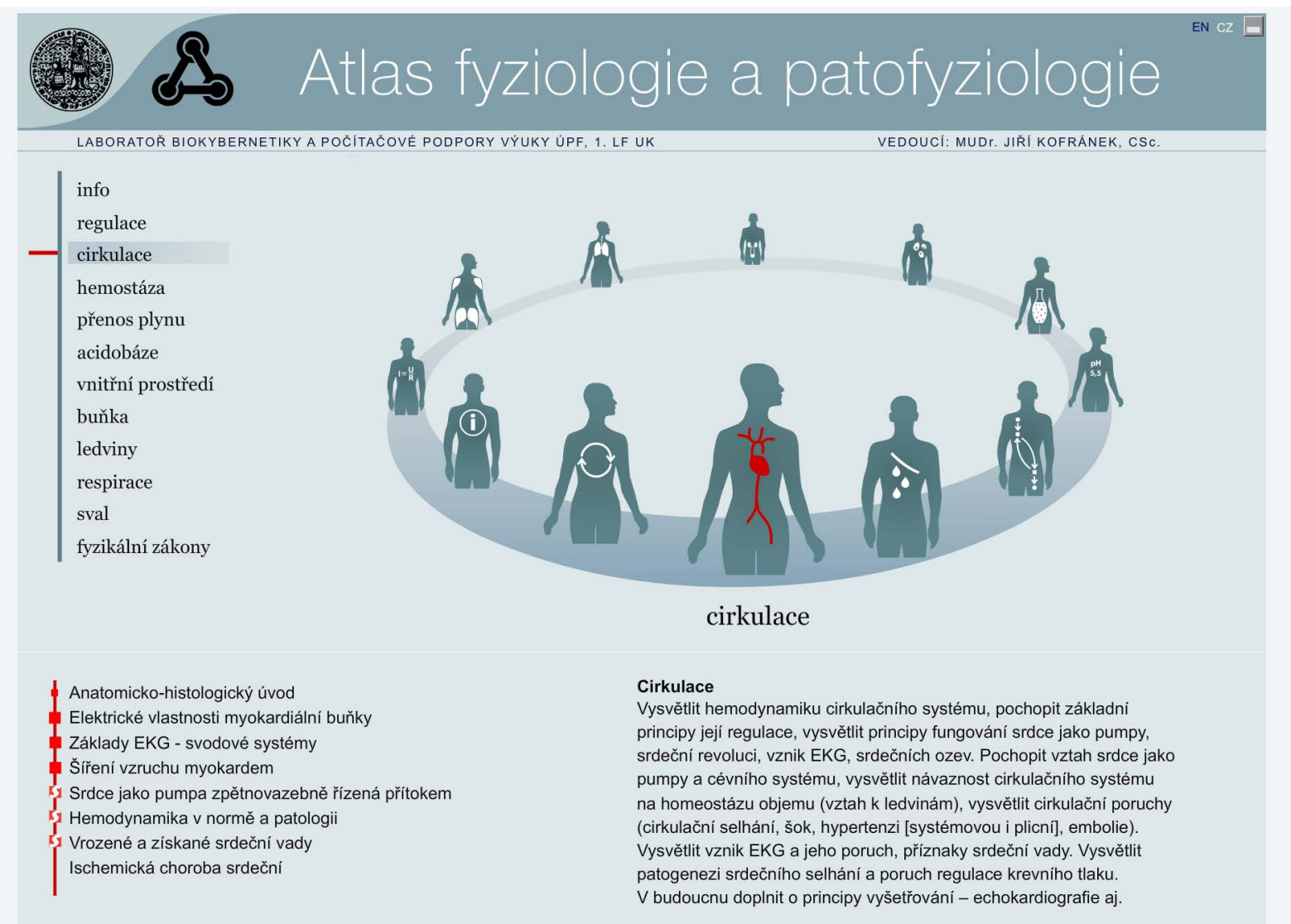

Obrázek 2 - Jednou z položek Atlasu fyziologie a patofyziologie (www.physiome.ct/atlas) je jednoduchý model cirkulace (položka cirkulace/Srdce jako pumpa zpětno-vazebně rízená prítokem).

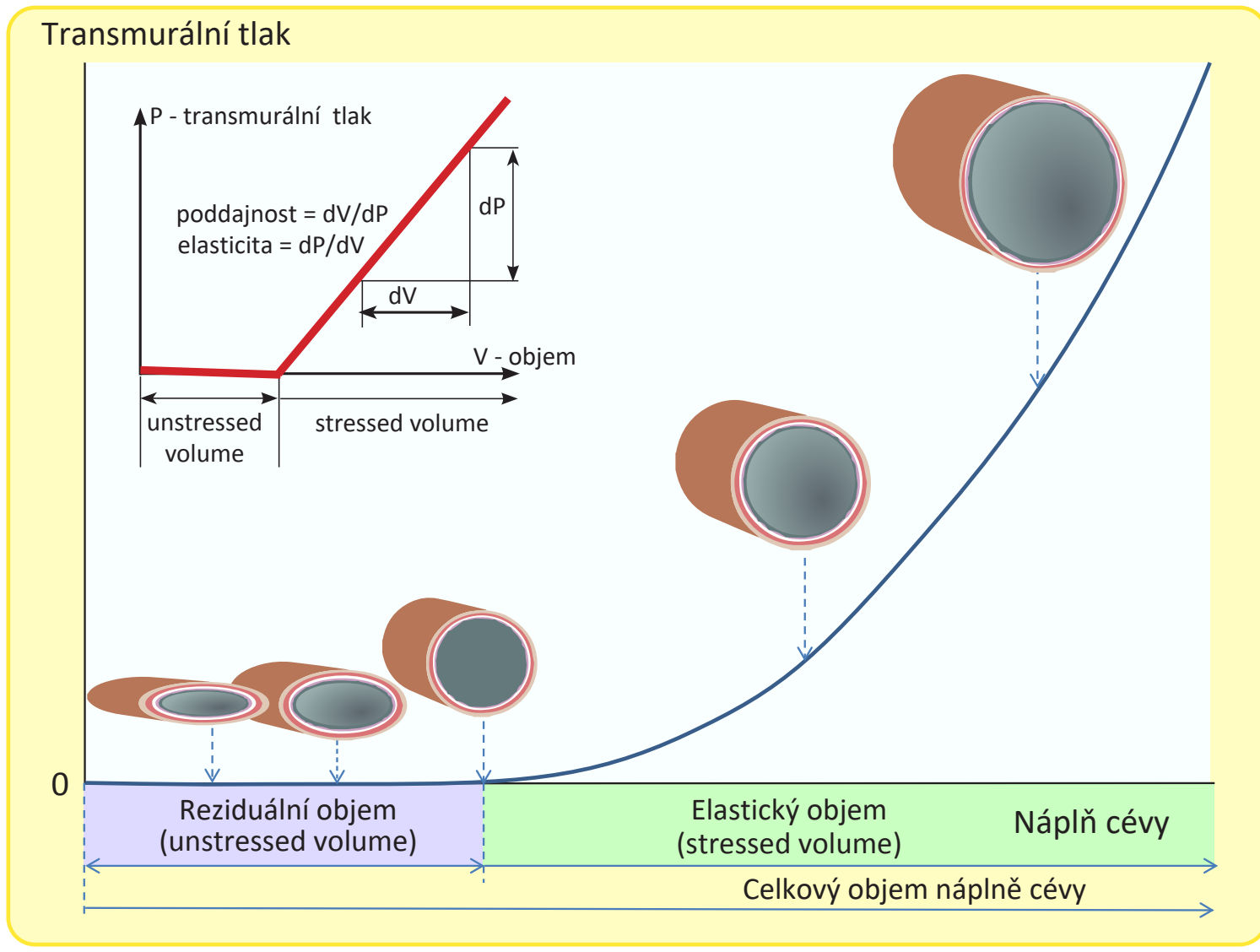

Obrázek 3 - Reziduální (neelastický) a elastický objem cévy. Při plnění krví do dosažení reziduálního objemu (unstressed volume) je transmurální tlak v cévě nulový. Když se céva začne dále plnit, začnou se napínat elastická vlákna a tlak v závislosti na elasticitě $(d P / d V)$, resp. poddajnosti (dV/dP) stoupá. 
systému, jehož pomocí je možné vysvětlit základní patofyziologické mechanismy, které se uplatňují při srdečním selhání a při rozvoji cirkulačního šoku.

Již dva roky tento model využíváme ve výuce patologické fyziologie na 1. lékařské fakultě. Všichni studenti s tímto modelem absolvovali dvouhodinový seminář, kdy pomocí simulačních her pod dohledem zkušeného pedagoga si průběžně přehrávali různé scénáře poruch krevního oběhu a cirkulačního šoku. Ukázalo se, že právě hra s modelem přispěla k lepšímu pochopení dynamických vztahů, které se uplatňují při těchto poruchách, než při klasické výuce.

Model je po strukturní stránce jednoduchý, a pro studenty medicíny je proto i po matematické stránce snadno pochopitelný. Model je tvořen instancemi tří komponent. Těmito komponenty jsou:

1. Odpory - průtok (Q) je dle Ohmova zákona úměrný tlakovému gradientu mezi vtokem (Pin) a výtokem (Pout):

$$
\mathrm{Q}=(\text { Pin }- \text { Pout }) / \mathrm{R}
$$

2. Elastické kapacitní cévy - jejich chování je zobrazeno na Obr 3. Pokud objem náplně cévy $(V)$ bude menší než reziduální (neelastický) objem (V0), pak transmurální tlak v cévě bude nulový. Bude-li větší, pak tlak (P) bude úměrný elastickému objemu (V-V0) a elasticitě (e) (tj. tuhosti) cévy a neprímo úměrný poddajnosti (c). Tedy:

$$
\begin{aligned}
& \text { Když } \mathrm{V}>\mathrm{V} 0 \text {, pak: } \\
& \text { jinak: } \\
& P=e^{*}(V-V 0)=(1 / c) *(V-V 0) \\
& \mathrm{P}=0 .
\end{aligned}
$$

Vliv kontrakce hladké svaloviny v kapacitních cévách na krevní tlak znázorňuje Obr. 4. Změnou reziduálního objemu (a mírným zvýšením elasticity, resp. mírným snížením poddajnosti) můžeme modelovat zvýšení tonusu kapacitních cév.

3. Srdeční pumpa je modelována tím nejjednodušším způsobem jako pumpa, jejíž průtok $(\mathrm{Q})$ je úměrný tlaku krve $(\mathrm{P})$ na jejím vstupu:

$$
\mathrm{Q}=\mathrm{k} P
$$

Tímto způsobem se modeluje Starlingova křivka - tj. závislost minutového objemu srdečního na plnicím tlaku. Ve skutečnosti je tato křivka nelineární - a zde je pro jednoduchost nahrazena přímkou. Čím větší je koeficient „,k“, tím výkonnější je pumpa zvýšením hodnoty koeficientu " $\mathrm{k}^{\prime \prime}$ modelujeme vliv sympatiku na frekvenci srdeční a inotropii srdce, poklesem koeficientu ", $\mathrm{k}^{\prime}$ můžeme simulovat insuficienci. Srdeční výdej je tady závislý pouze na preloadu (navíc pouze lineárně), tlak v arteriálním rečišti (afterload) na výkon srdce se v tomto modelu neuvažuje.

Struktura modelu sestává z dvou odporů (plicního a celotělového systémového), čtyř bloků elastických kapacitních cév (systémových arterií, systémových žil, plicních arterií a plicních žil) a dvou srdečních pump. Dále je v modelu uvažován celkový objem krve a celkový neelastický reziduální objem krve (součet objemů čtyř bloků elastických kapacitních cév).

Ovládání modelu (Obr. 5) je velmi jednoduché a slouží především k ujasnění základních vztahů mezi jednotlivými regulovanými proměnnými oběhového systému, tj. tlaky, objemy a průtoky $v$ malém a velkém oběhu, a základními veličinami, které tlaky, objemy a průtoky ovlivňují - tj. plicním a systémo-

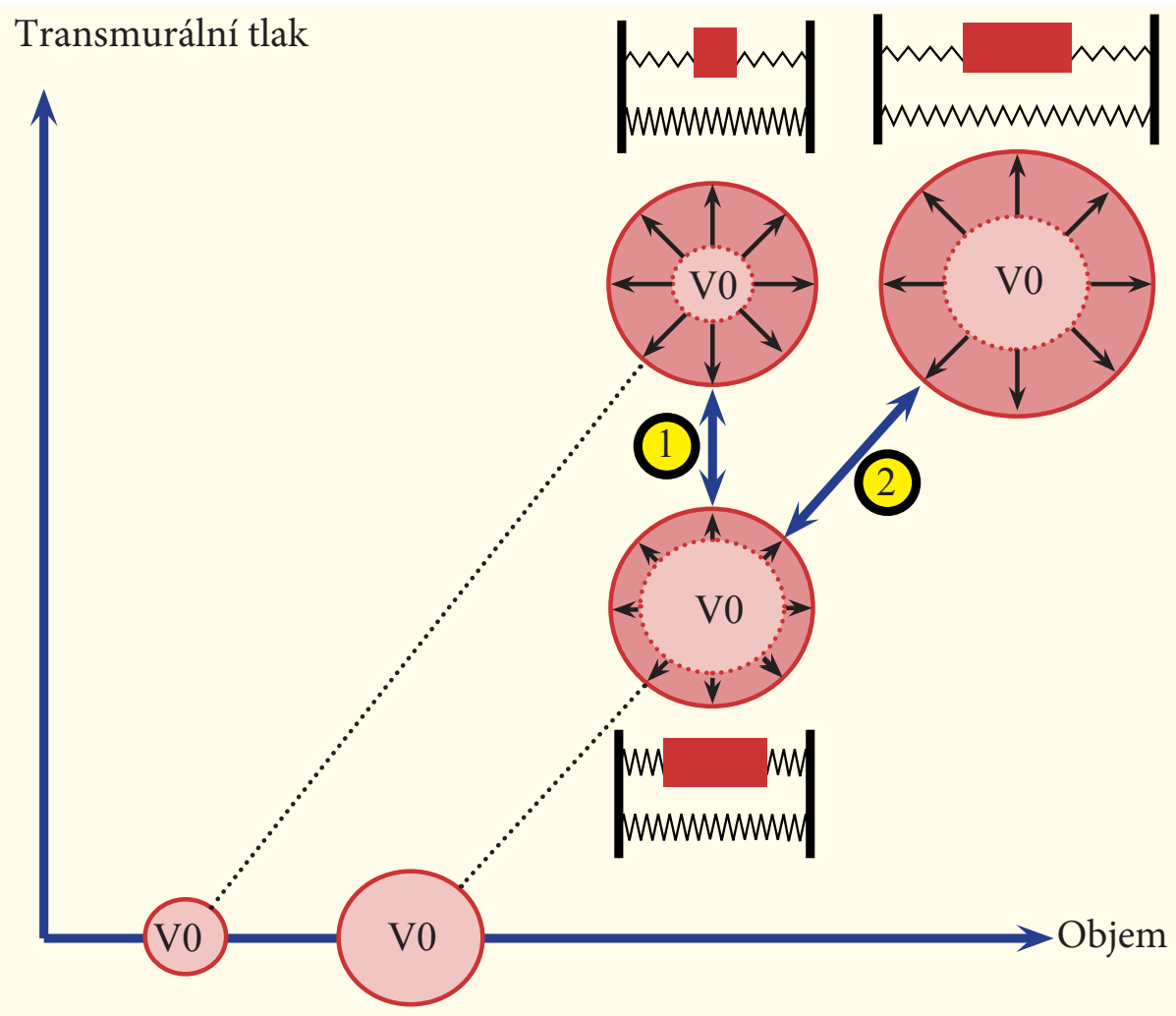

Obrázek 4 - Vliv zvýšeného svalového tonusu na tlak v cévě (1). Červeným obdélníčkem je znázorněna svalová buňka, pružinky jsou elastické elementy svalové tkáně. Když se sval kontrahuje, elastické elementy se více napínají, tlak uvnitř cévy stoupá, reziduální objem (unstressed volume) se snižuje, a tím se zvýši i elastický objem náplně cévy (stressed volume). Díky paralelnímu zapojení elastického elementu při zvýšení tonusu cév se mírně zvyšuje tuhost (elasticita) cévy - snižuje se její poddajnost (křivka transmurální tlak - objemová náplň cévy je strmější). Zvýšení svalového tonusu hladké svaloviny velkých kapacitních cév tak vede ke zvýšení tlaku. Vzestup tlaku může být také způsoben zvýšením objemu náplně cévy (2). Díky tomu objem cirkulující krve ovlivňuje tlak v cévách. 

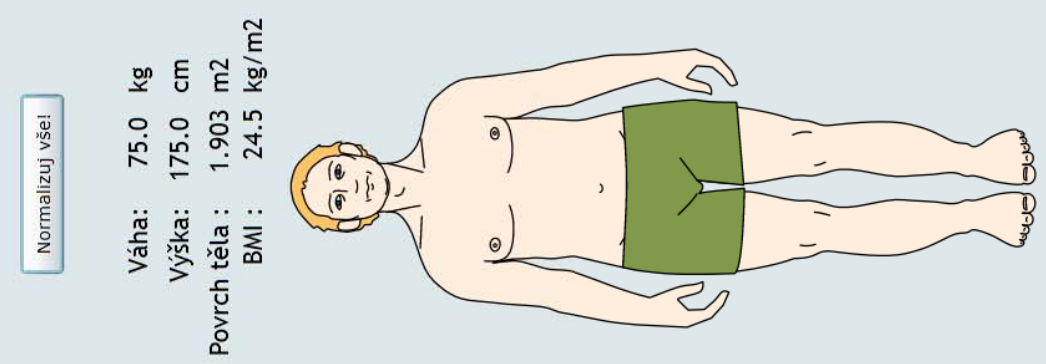

ت음
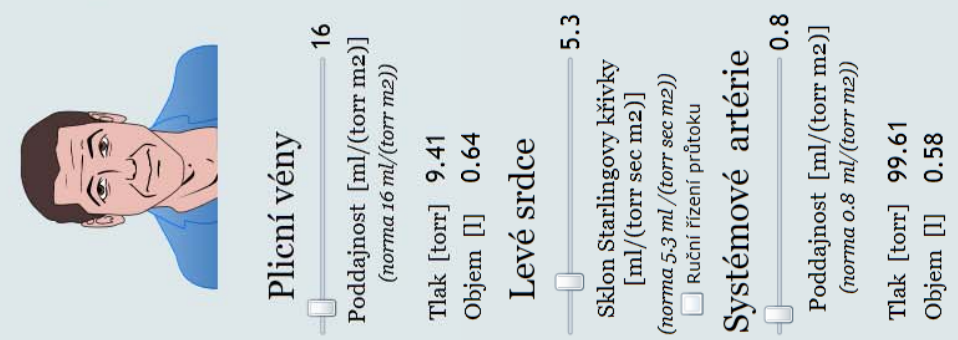

总苛

需

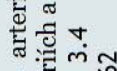

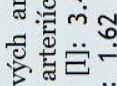

응을

密.

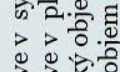

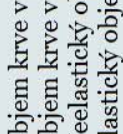

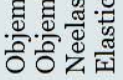

二우 $\stackrel{+}{\mathrm{r}}$
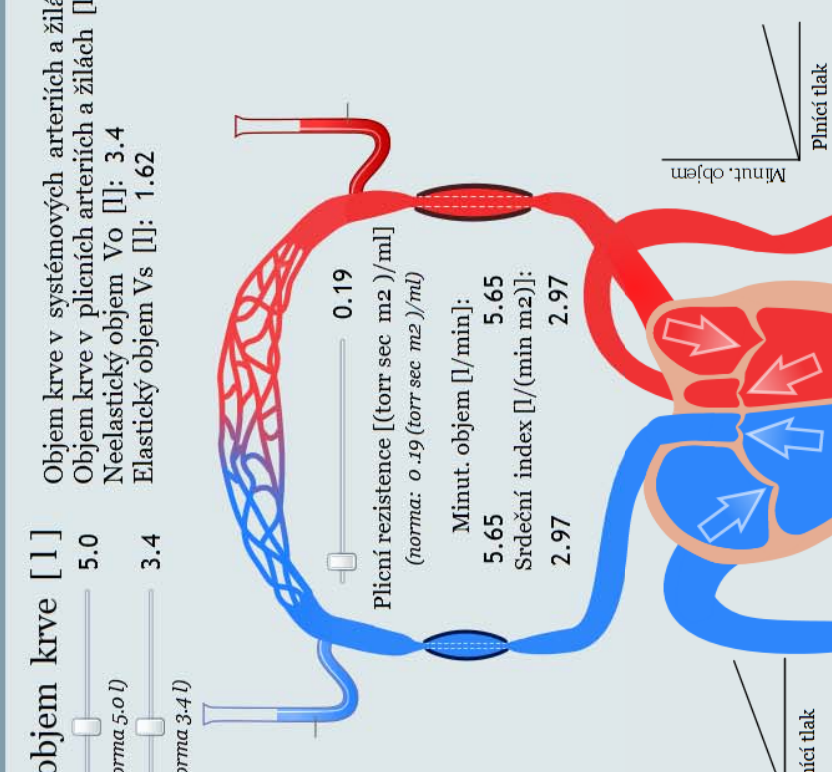

2

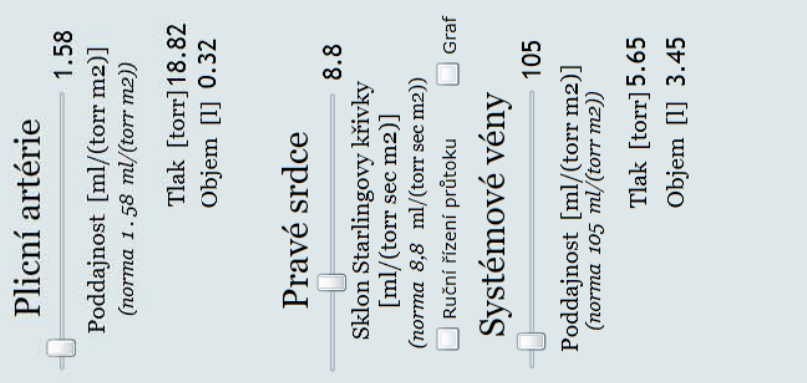

กับ

के

है है

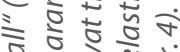

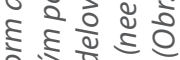

ว डิ

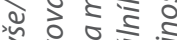

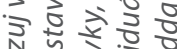

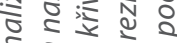

ㅎำ

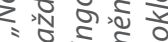

辛安言势

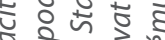

का

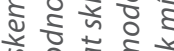

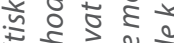

กิ

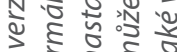

* 하워

ㄷํำ है

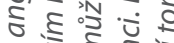

०

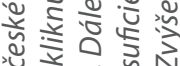

脑包N

ฮे से है है

ว 동ำ

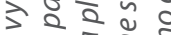

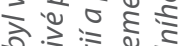

은 는 훙

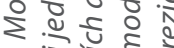

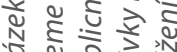

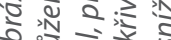

은

홍ํำ

궁ำ

ะ ํㅝㄴ

ํํำ

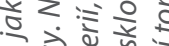

की

के है 둴

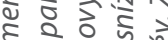

จे टे ญे ญ

讨

ㄱำ

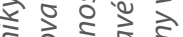

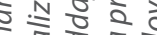

रे है $0 \circ$

ह

\& 20

दิ है ठ․ำ

ชำ ำ ㅇำ

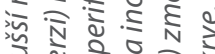

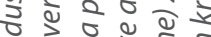
을 है

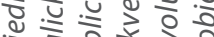
के के क्षे 1 है ฮิ ข้อ

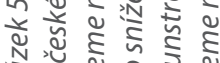
ํำㄴำ 
vým periferním odporem, čerpací funkcí levé a pravé komory v modelu realizovaném jako sklon Starlingovy křivky, objemem krve, tonusem velkých cév - modelovaným jako změna reziduálního (unstressed) objemu a změnou poddajnosti cév.

Organismus tyto veličiny reguluje (rezistence je řízena nervovou a humorální regulací, změna frekvence a inotropie mění sklon Starlingovy křivky, tonus velkých žil mění reziduální objem a jejich poddajnost a objem cirkulující krve je ovlivňován především činností ledvin, renin-angiotenzinovou regulací aj.). V agregovaném modelu jsou však tyto veličiny vstupními (tj. neregulovanými) veličinami - cílem simulační hry s tímto modelem je ozřejmit si význam těchto veličin pro řízení tlaků, minutového objemu srdečního a distribuci objemu krve mezi jednotlivými částmi krevního řečiště.

Simulační hrou s tímto jednoduchým modelem oběhu je možné názorně vysvětlit, jakým způsobem se uplatňuje regulace základních veličin oběhového systému v patogenezi různých poruch oběhového systému.

Pro představu o možnostech modelu uvádíme na Obr. 5 -14 některé simulační výukové hry s modelem.

Model byl implementován jako interaktivní obrázek (Obr 5). Můžeme $v$ něm interaktivně nastavovat důležité parametry sklony Starlingových křivek (Obr. 6), periferní a pulmonální rezistence, poměr neelastického a elastického objemu náplně cév, poddajnosti arterií a vén a také celkový objem krve.

Model záměrně nemá implementované fyziologické řízení. Cílem simulačních her s tímto modelem je ozřejmit si vliv parametrů hemodynamiky (inotropie a frekvence srdce, odporů, poddajností, svalového tonusu velkých cév a následné změny elastického a neelastického objemu i objemu cirkulující krve), které jsou v organismu řízeny, a pochopit tak význam regulačních zásahů.

Model umožňuje nahradit srdce krevními pumpami. Pokud nahradíme jak levé, tak i pravé srdce externími krevními pumpami, pak se snadno přesvědčíme, že malé rozdíly v nastavení průtoku levého a pravého srdce vedou $\mathrm{k}$ akumulaci objemu krve $v$ malém nebo velkém oběhu a následným prudkým změnám tlaků. Pokud externí pumpu umístíme jenom do jedné poloviny srdce, zbývající srdeční komora se přizpůsobí nastavenému minutovému objemu a průtok levým a pravým srdcem bude stejný. Když např. pumpa umístěná místo pravého srdce zvýší srdeční minutový objem, v plicních žilách se bude hromadit krev. Tím ale stoupne plnicí tlak pro levou komoru a důsledkem bude (podle Starlingova zákona), že minutový objem levé komory se zvýší a vyrovná se nastavenému minutovému objemu pravé komory. Pokud naopak průtok srdeční pumpy v pravém srdci snízíme, do plicního oběhu bude vtékat méně krve než z něj vytékat a náplň plicních žil - a tudíž i plnicí tlak pro levé srdce - se sniží. Díky posunu po Starlingově křivce se snízí i minutový výdej levé komory na úroveň, kterou jsme nastavili $v$ čerpadle pravé komory. Proto můžeme nastavením průtoku pravostranné srdeční pumpy regulovat minutový objem i levé komory. Pokud čerpadla vyměníme, můžeme na modelu sledovat, že i pravé srdce se přizpůsobí podle nastavení minutového průtoku externím čerpadlem levé komory. $Z$ těchto simulačních experimentů je jasné, že význam Starlingova zákona - že srdeční výdej závisí na plnicím tlaku - spočívá v tom, že umožňuje přizpůsobení jedné srdeční komory druhé. $Z$ toho mimo jiné také vyplývá, že při insuficienci pravého srdce a snížení minutového průtoku pravé komory dojde i ke snížení minutového průtoku levé komory (a obráceně).

Model umožňuje zkoumat vlivy, které rídí žilní návrat, a v simulačním experimentu vytvářet křivky venózního návratu (Obr. 7-12).

Pomocí simulačních her s modelem můžeme zkoumat vývoj srdečního selhání a význam a uplatnění jednotlivých adaptač- ních faktorů při selhávání oběhu (Obr. 12-14).

Model ve výuce patofyziologie cirkulace využíváme šíreji, než je demonstrováno na Obr. 5-14. Na modelu např. demonstrujeme specifické rysy, kterými jsou charakterizovány jednotlivé druhy šoku (např. ukazujeme, jak se při různých druzích šoku posouvají Starlingovy křivky a křivky venózního návratu).

Model cirkulace je hraničně jednoduchý - vystihuje však základní parametry, které integrálně charakterizují cirkulační systém jako celek. Je zajímavé, že obdobný model se dá využít i v klinice - např́klad skupina ve Vědeckém kardiochirurgickém centru A. N. Bakuleva v Moskvě používá obdobný model, jehož parametry individuálně identifikuje s klinickými daty konkrétních pacientů (Лищук 2007-2017).

\section{Krevní plyny a poruchy perfúze}

Úloha oběhového systému nespočívá jen v přečerpávání několika litrů tekutiny. Důležité je, že oběhový systém zajištujue distribuci látek po celém organismu, zejména krevních plynů. Pro pochopení souvislostí cirkulace, respirace a přenosu krevních plynů slouží naše další interaktivní pomůcka - model krevních plynů (Obr 15-16), kterou je také možno nainstalovat z námi vyvíjeného interaktivního Atlasu fyziologie a patofyziologie (http://physiome.cz/atlas) [15-17].

Na modelu můžeme např. sledovat, co se stane, když je tkáň hypoperfundovaná. Při omezení perfúze dochází ke snížení dodávky kyslíku do tkání - připomeňme si, že dodávka kyslíku (D02) je množství kyslíku, které přitéká za časovou jednotku arteriální krví do tkání, což závisí na perfúzi (Q) a celkové koncentraci kyslíku v arteriální krvi (CaO2):

$$
\mathrm{DO} 2=\mathrm{CaO} 2 * \mathrm{Q}
$$

Dodávka kyslíku do tkání poklesne při snížení $\mathrm{CaO} 2$ (at’ již $v$ důsledku poklesu arteriálního $\mathrm{PO} 2$, či při poklesu koncentrace hemoglobinu) nebo při snížení perfúze tkáně. Připomeňme, že spotřeba kyslíku v tkáni (VO2) je určována především metabolickými potřebami tkáně (tj. např. poměrem koncentrací ADP/ ATP) a nikoli koncentrací kyslíku, dokud koncentrace kyslíku nepodkročí kritickou hladinu. Omezení perfúze sníží dodávku kyslíku. Pokud v mitochondrii bude parciální tlak kyslíku nad dva $\mathrm{mmHg}$, spotřeba kyslíku se nesníží. Tkáň bude odebírat stejné množství kyslíku, zvýší extrakce kyslíku z arteriální krve (VO2/ DO2), hladina kyslíku v tkáni se sníží - sniźí se také koncentrace kyslíku a PO2 v odtékající venózní krvi (která je ekvilibrována s pO2 v tkáních). To vše si můžeme názorně demonstrovat na simulačním modelu (Obr. 17-18).

Tkáňová hypoxie při omezení perfúze do tkání je vcelku běžně známý fakt. Ne vždy si ale uvědomujeme, že zároveň v hypoperfundované tkáni dochází k hyperkapnické acidóze. Arteriální acidobazická rovnováha může být normální (dokud se neprojeví následná laktátová acidóza). Snížení perfúze totiž vede ke snížení rychlosti odtoku CO2 z tkání, v důsledku toho se $v$ hypoperfundované tkáni začne hromadit oxid uhličitý. Ten ve spojení s vodou disociuje na bikarbonát a vodíkové ionty, které se v buňkách váží na proteiny. Vazba vodíkových iontů na makromolekuly bílkovin mění jejich prostorovou konformaci a následně poškozuje jejich funkci. Snižuje např. enzymovou aktivitu komplexu enzymů zodpovědných za odstraňování kyslíkových radikálů. Poškození enzymů přetrvává po obnovení cirkulace, což je jeden z patogenetických mechanismů reperfúzního poškození. O tíži hypoperfuze s následnou hypoxií a hyperkapnickou acidózou svědčí, že venózní krev z postižené tkáně odtéká. Po jejím smíchání s venózní krví odtékající z nepostižených tkání se hodnoty krevních plynů změní a proto hodnoty PO2 a PCO2 ve smíšené venózní krvi neodrážejí rozsah hypoxických a acidotických postižení hypoperfundovaných tkání, což je možné názorně demonstrovat na modelu (Obr 18). 


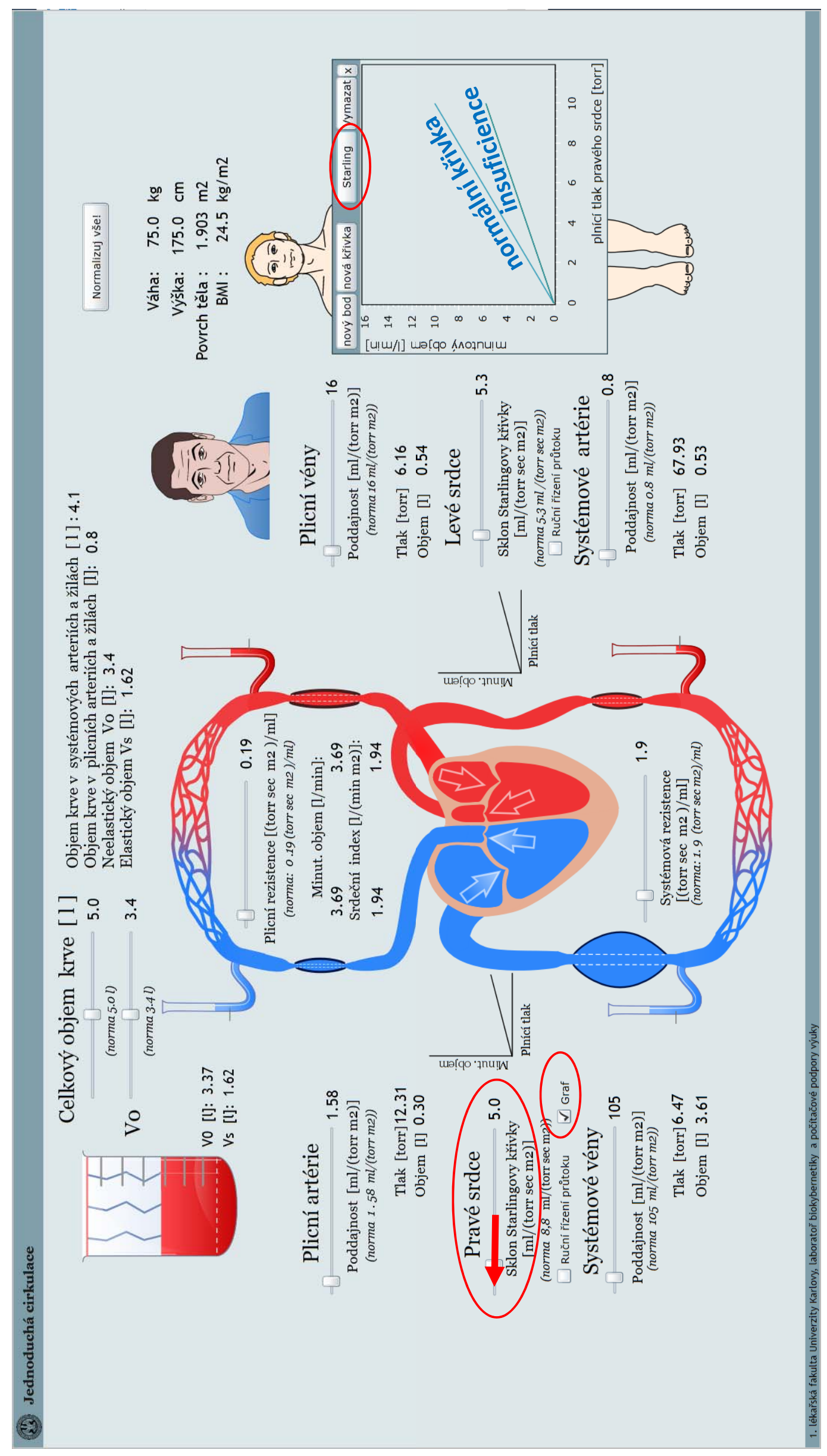




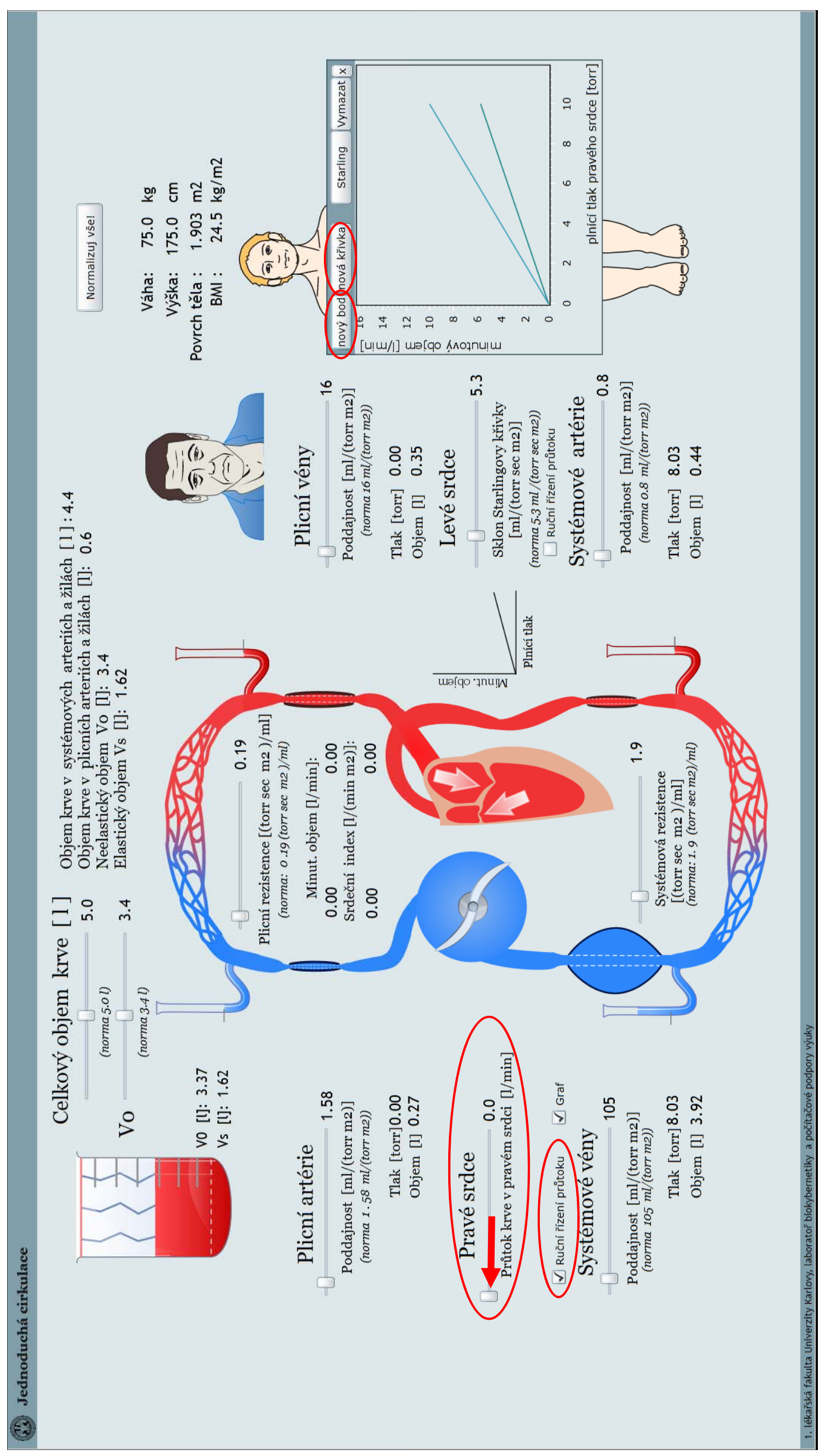

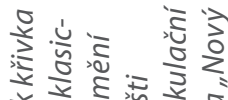

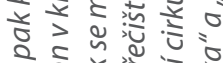

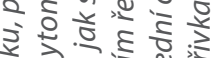

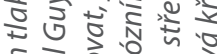

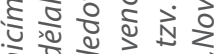

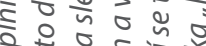

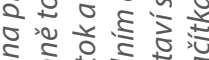

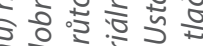

ह : $\frac{0}{0}$.

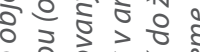

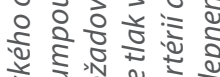

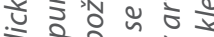

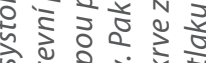

जे है हैं

\&े है है हิ ज्ञ

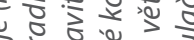

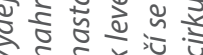

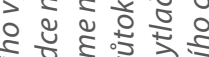

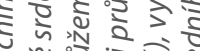

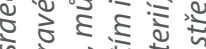

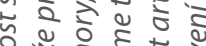

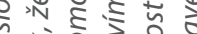

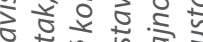

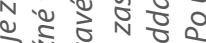

है है हैं

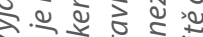

0 0 워

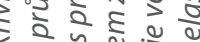

० व

ถิ

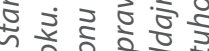

ก .7 .

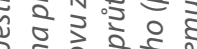

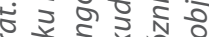

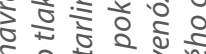

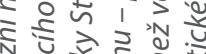

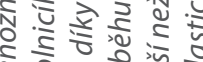

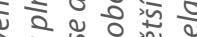

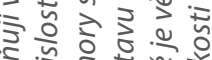

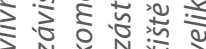

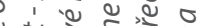

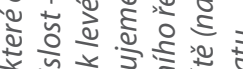

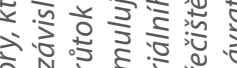

告

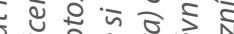

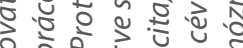

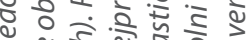

ल.

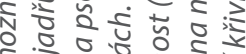

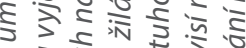

ब

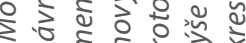

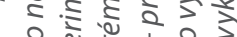

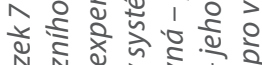

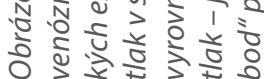



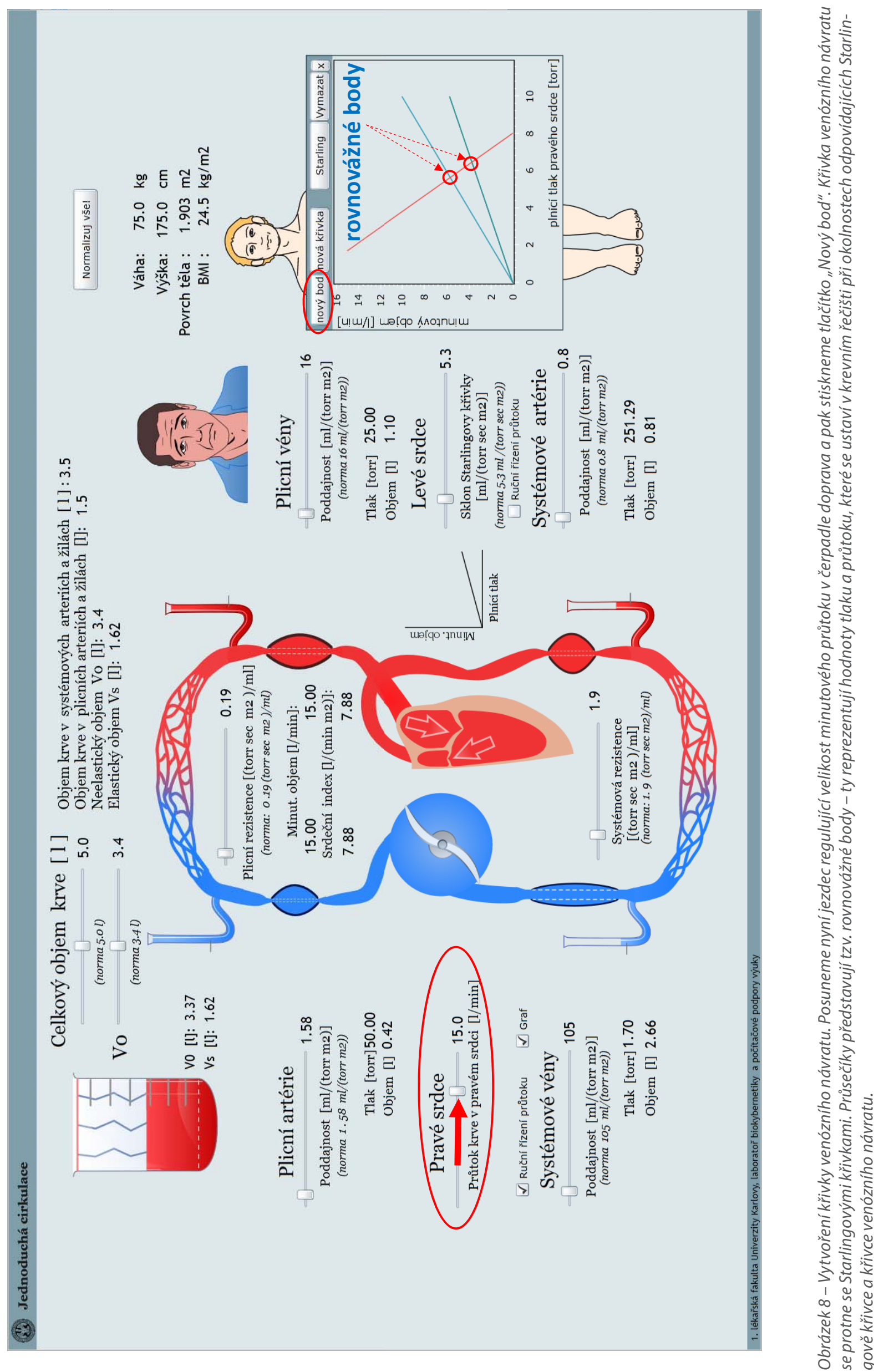

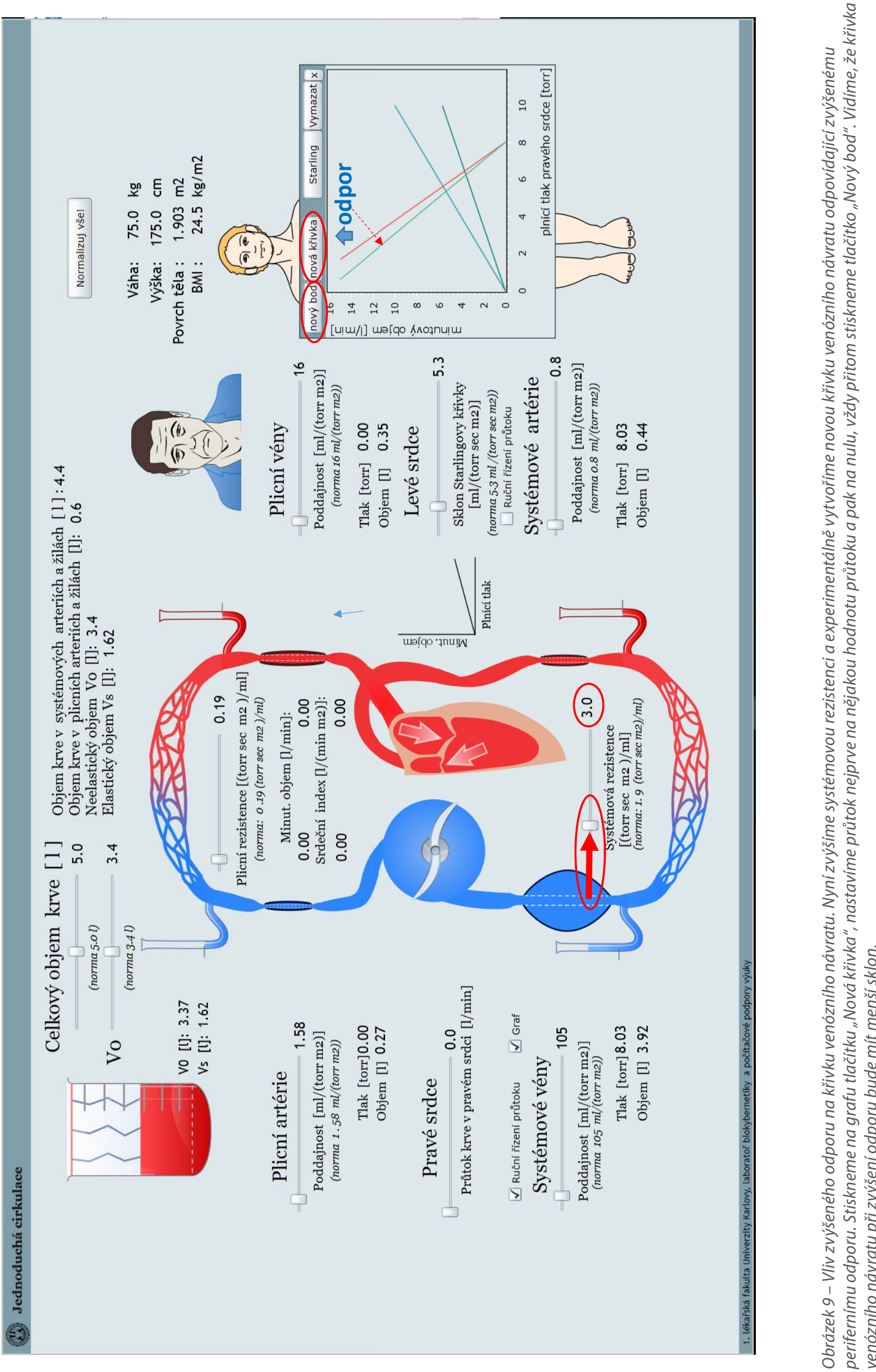


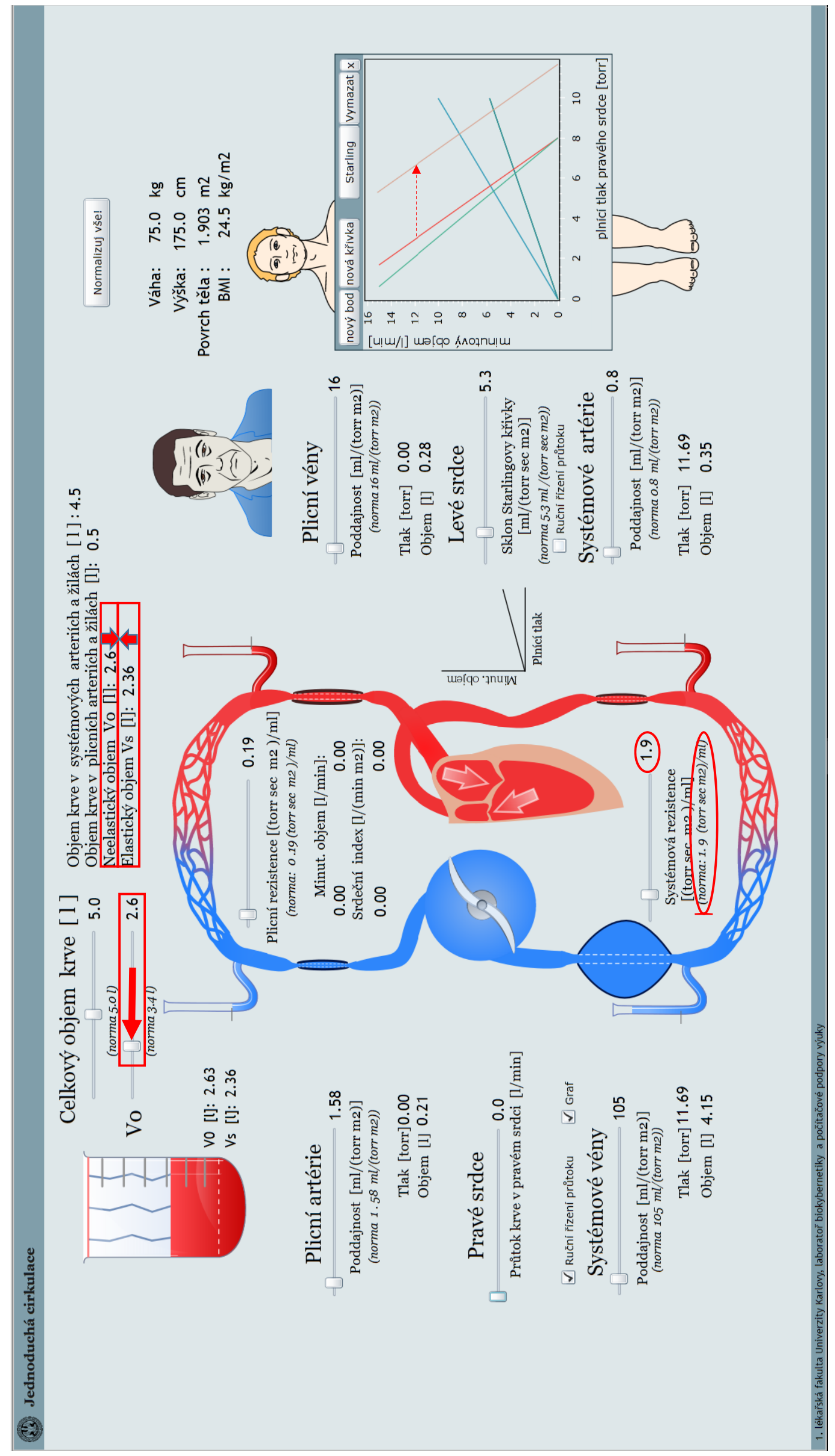

ร.

ㅇำ

i. 定

है

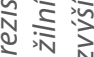

है จั้

竞这吉

药 है

$\sum$ 恼.

m

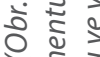

ह

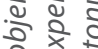

로

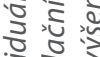

ํ.

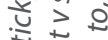

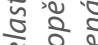

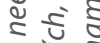

.

辛辛

in

넌

ชั

$\leq \geq 8$

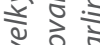

은현

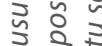

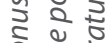

온 항

है ह

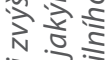

证

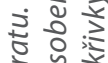

을

ㅇำ

就方

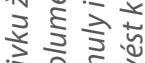

这高

워ํ

जิ

के डิ

일 융

용요

2)

옹요용

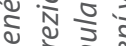

登会

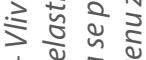

1 为

을 है

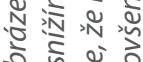



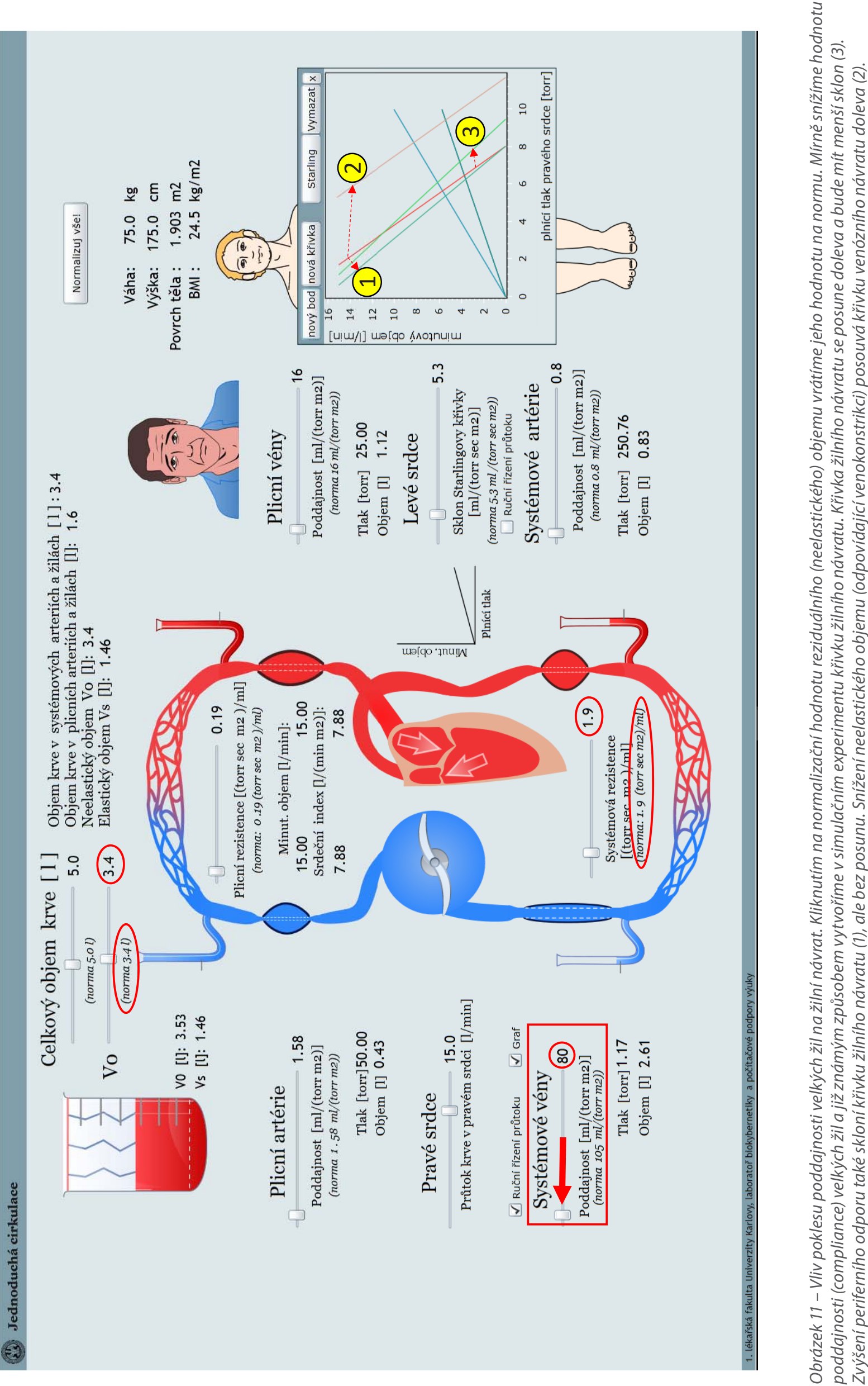


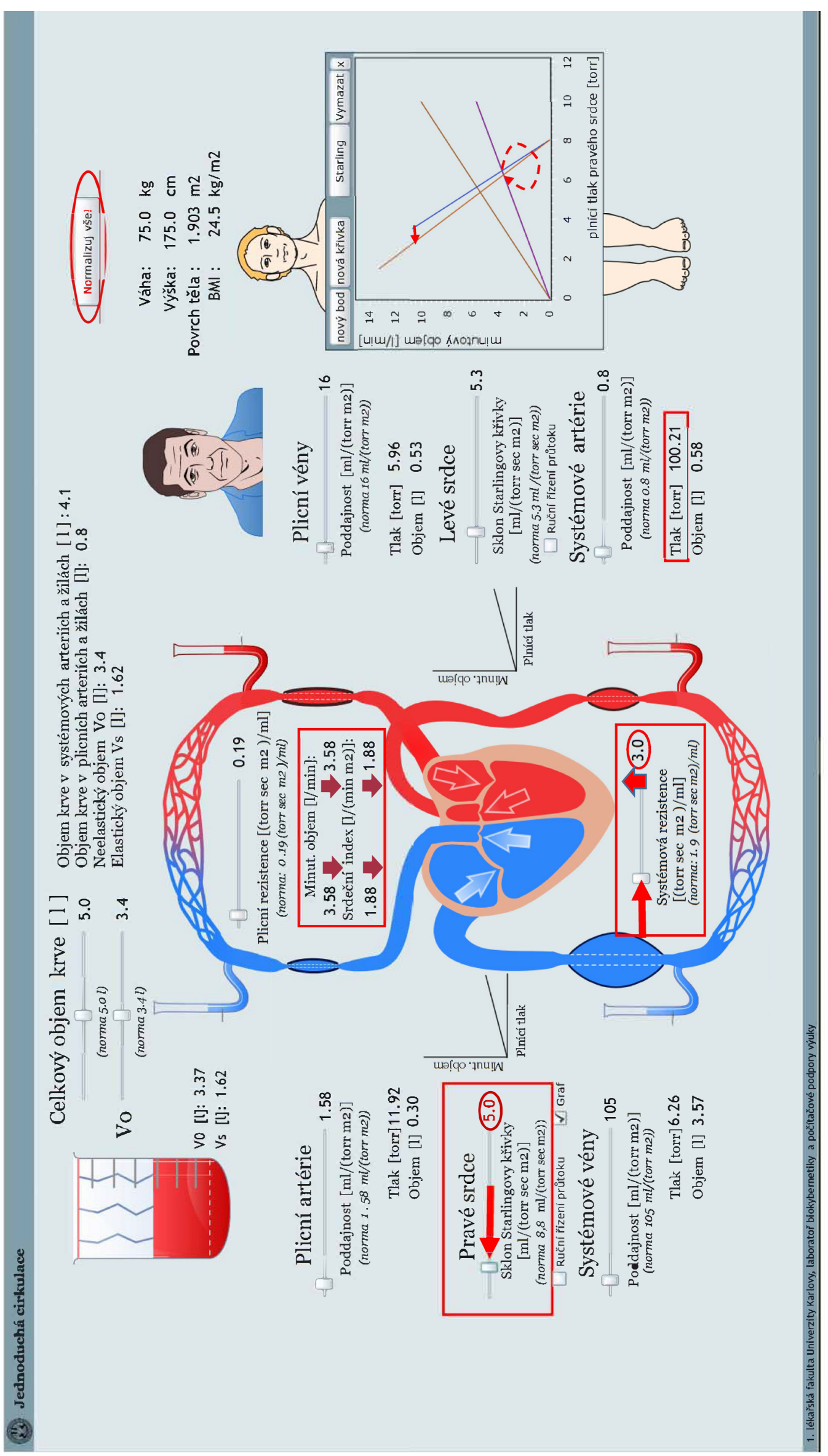

เ⿱亠幺十้

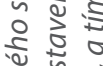

वे

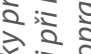

is

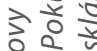

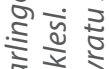

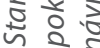

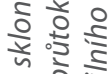

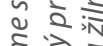

हो

要

वे हू

율

咅 हो

है:

을 $\frac{1}{2}$

ते है

然:

है

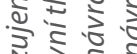

के

है

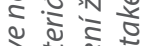

称

टे है के 을

نั่

촣 승 능

1ิ

วิ ฆั

है

กิ

ㄴ.

웡 항요

๘

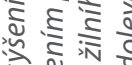

충ำ

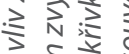

। है है

논

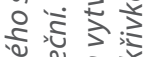

वे 는

ㅎํㅇ

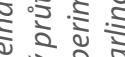

군

है

彭彭

वे.

ษ 흘

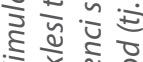

卷过

$\therefore$ के ले

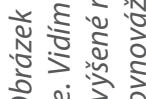




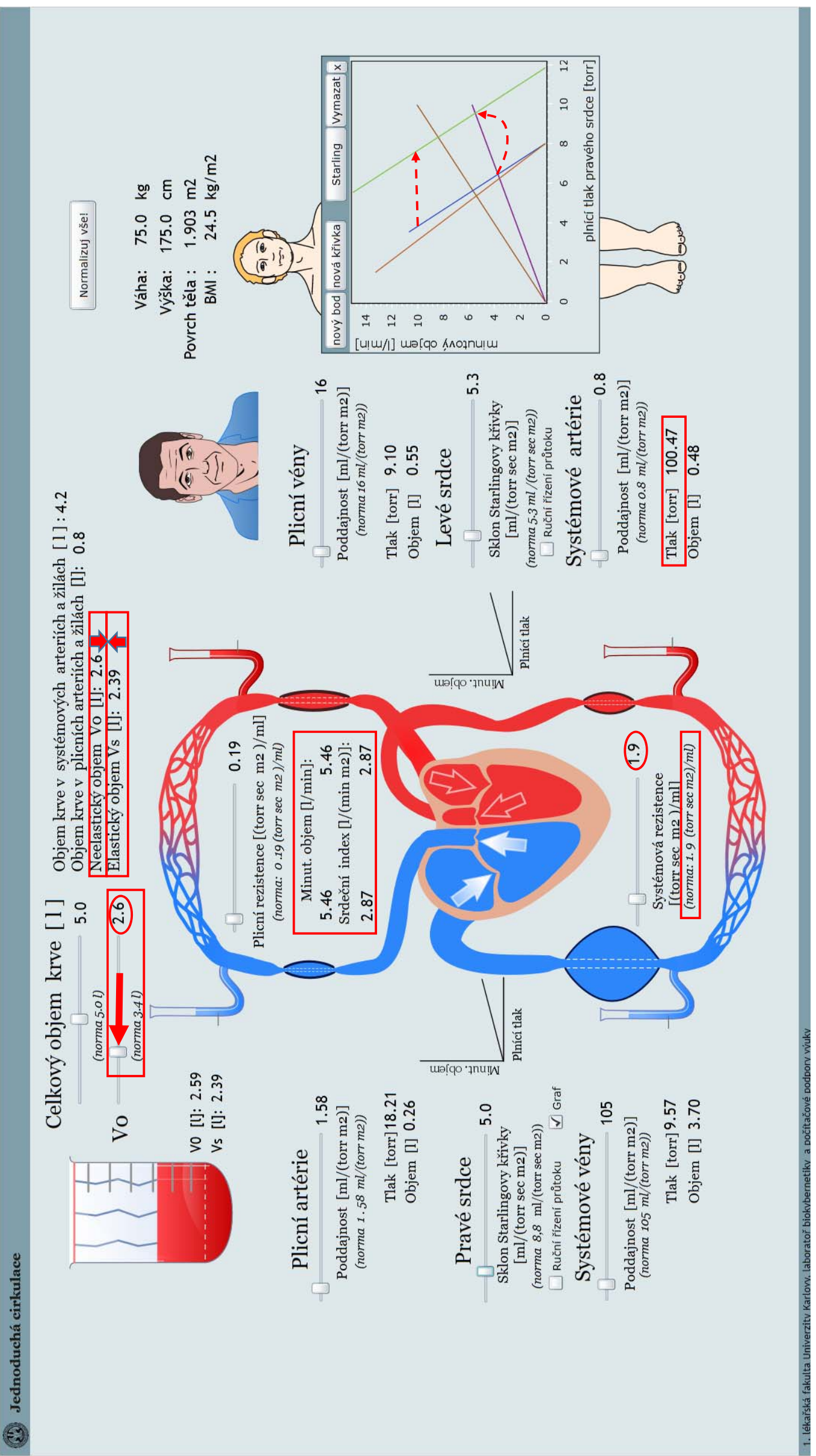

$\frac{2}{8} \cdot \frac{1}{8} \cdot \frac{1}{8}$

पू

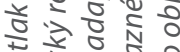

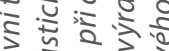

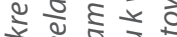

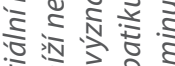

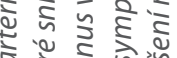

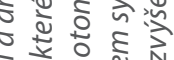

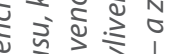

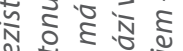

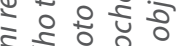

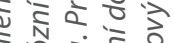

ญำ

है.

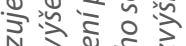

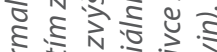

을

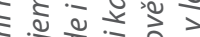

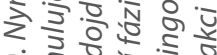

旅

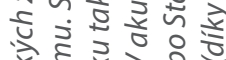

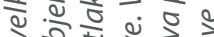

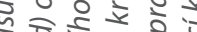

पू

วั

है

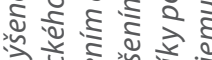

응

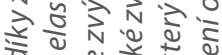

일

उำ

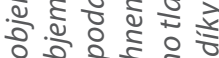

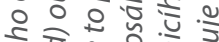

는

पू

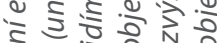

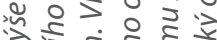

ते हूं हैं हैं

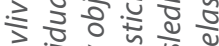

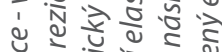

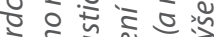

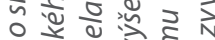

. ज行

वे ํํำ

요요

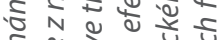

该

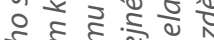

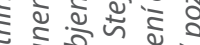

政

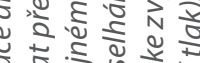

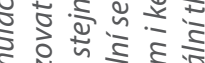

है:

1 हो ठ혛ำ

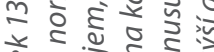

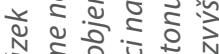

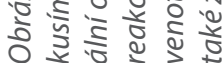



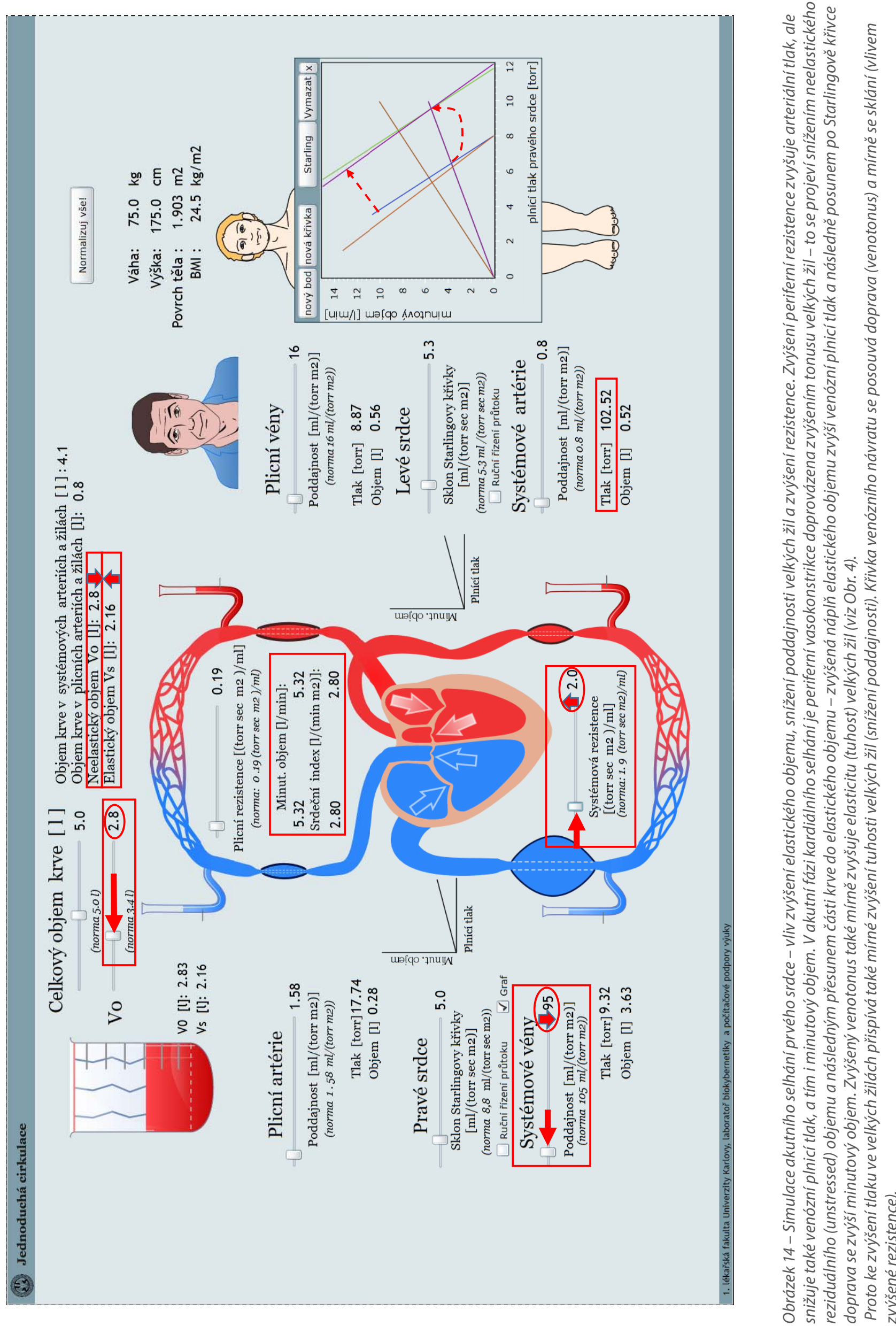


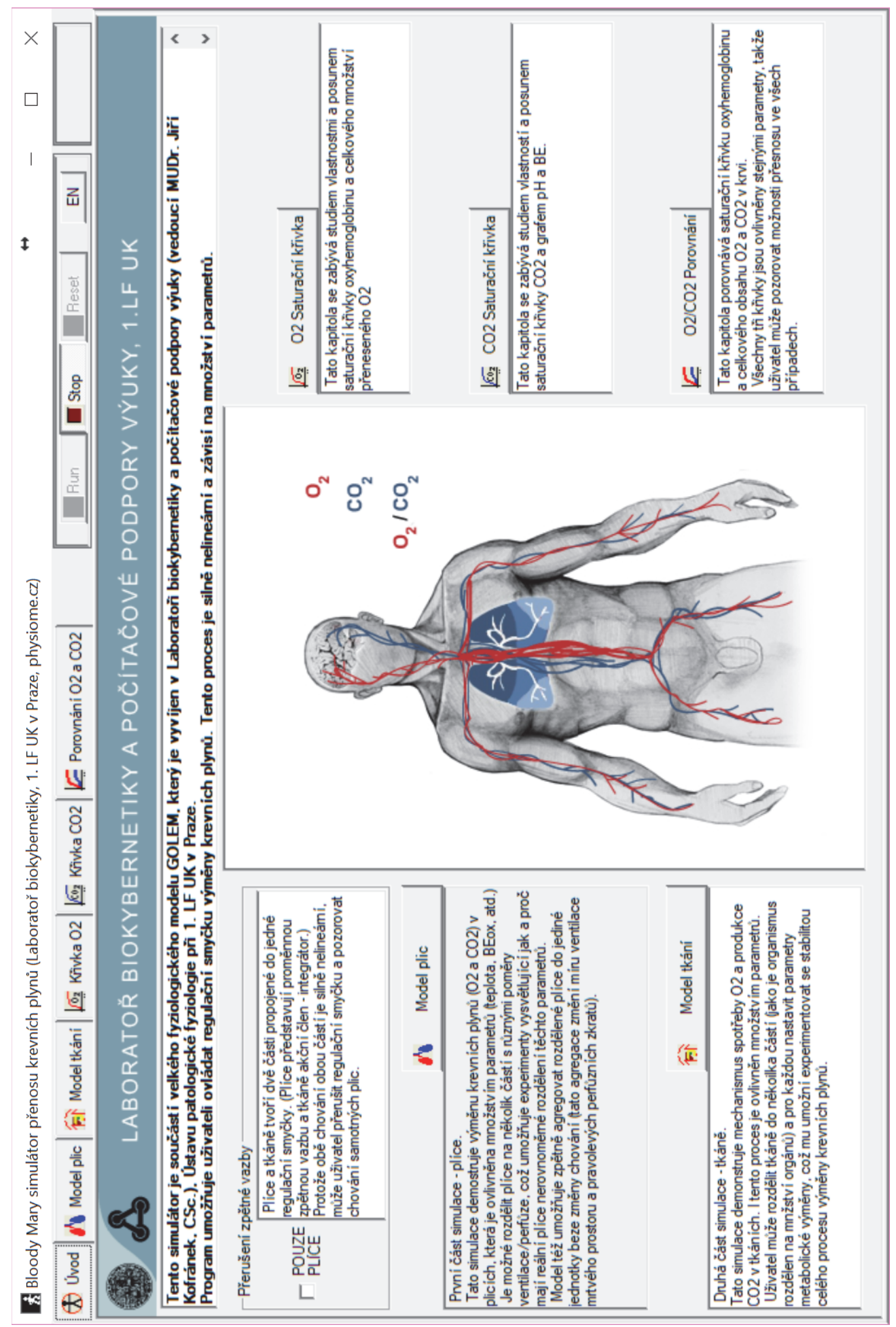




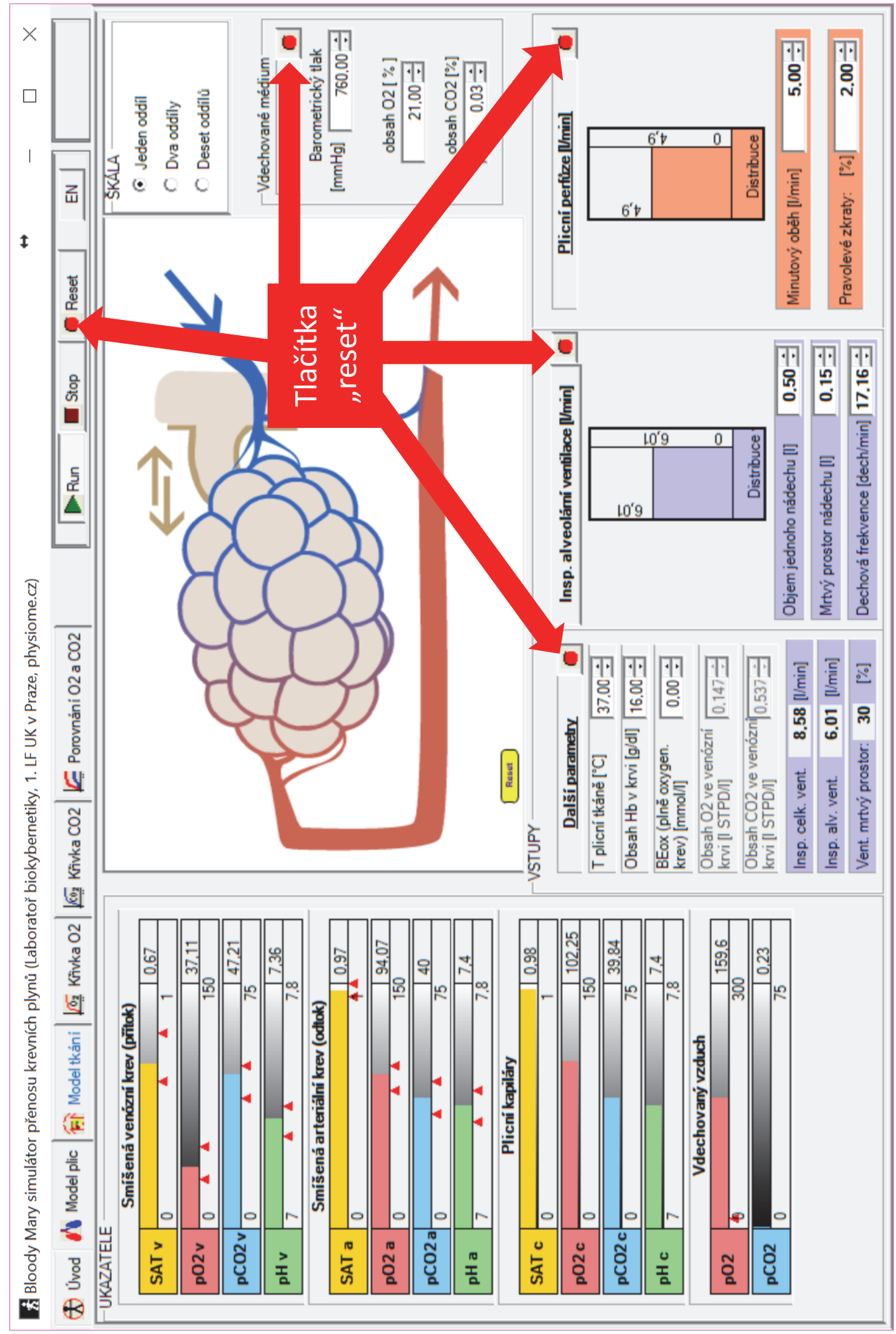

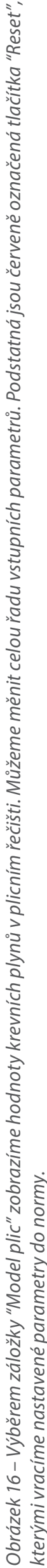




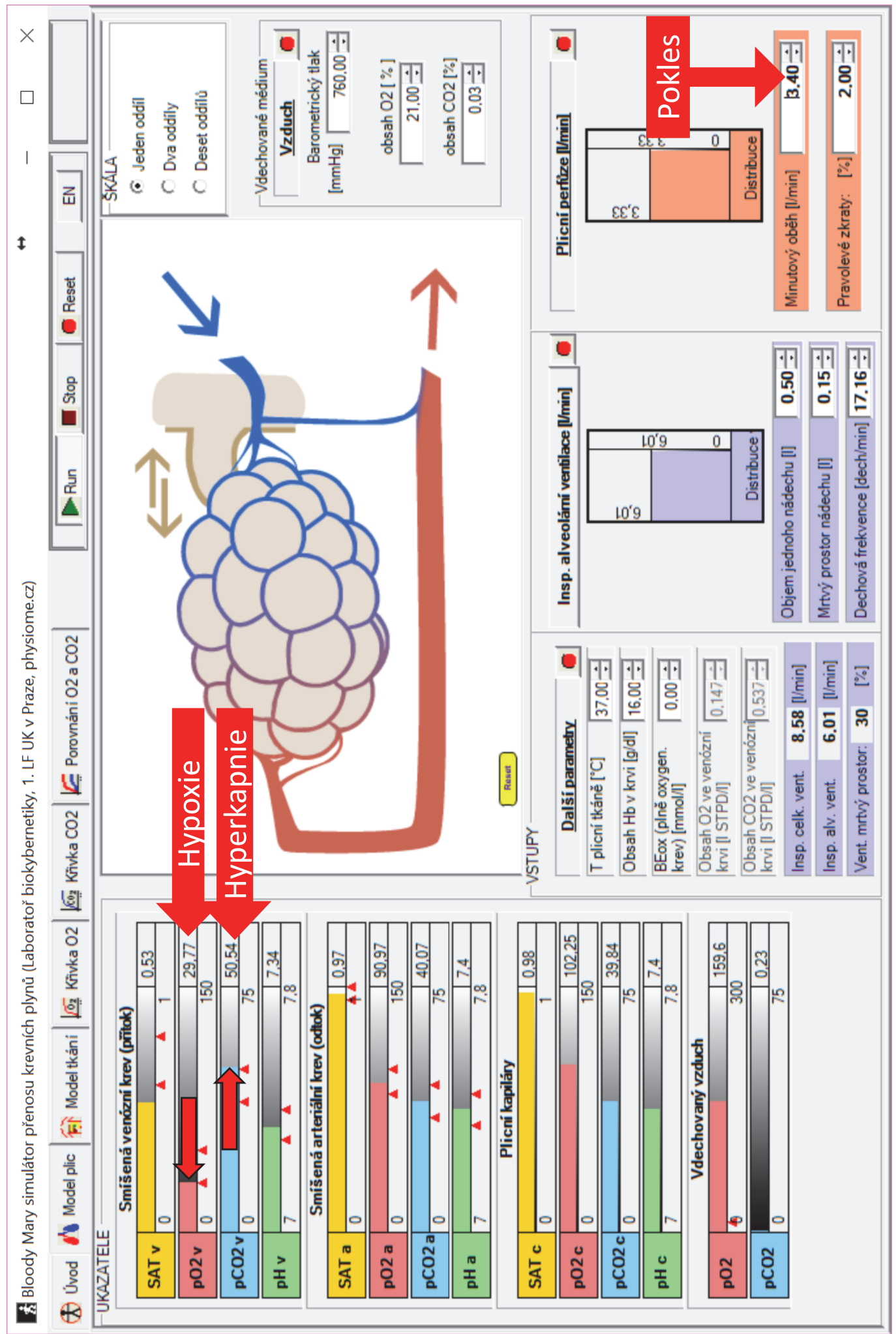

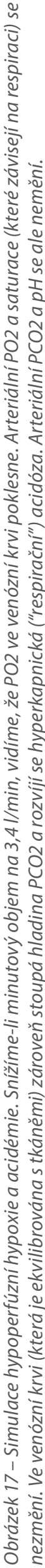




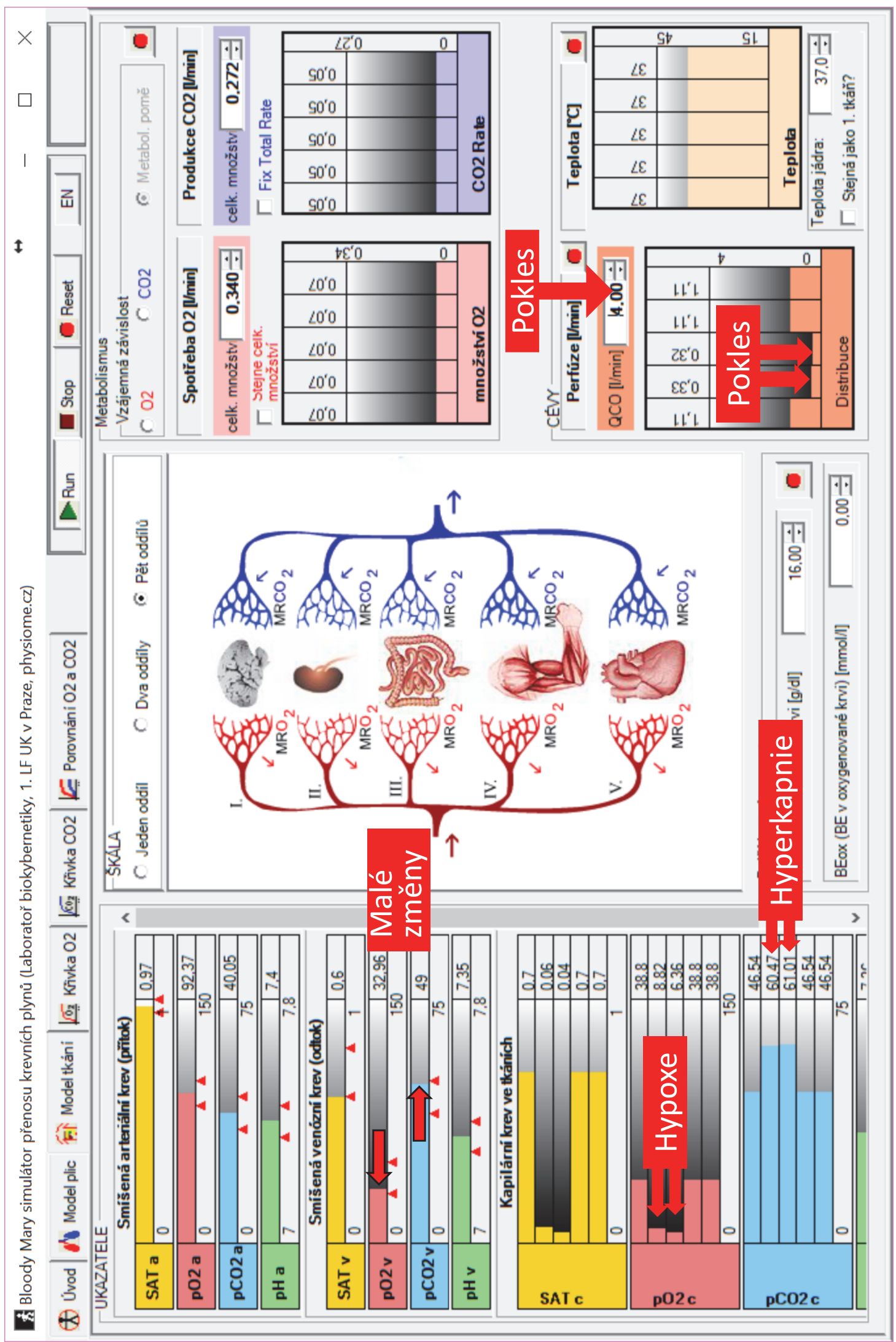

$\frac{1}{2}$

๕ัะ

옹

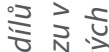

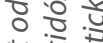

$\therefore$

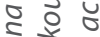

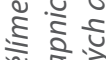

in

in

थ वे

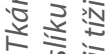

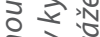

के ते

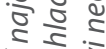

흔

중

, ํํำ

원

จे है

ว $ว$ ั้

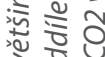

a ह ㄷำ

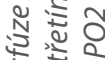

ญำ 응

종ำ

둥요

टे के

एँ

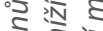

초ำ

综

ปั $\frac{0}{\circ}$

吃

곤ำ

한

응

워

है 촌

है है ह

ㅇํㅇ

ㅊำ

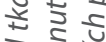

के है

次

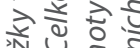

정 농

No엉

हญ. 촌

\& 동

今

$\infty$ 는

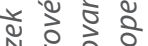

ㄱำ 


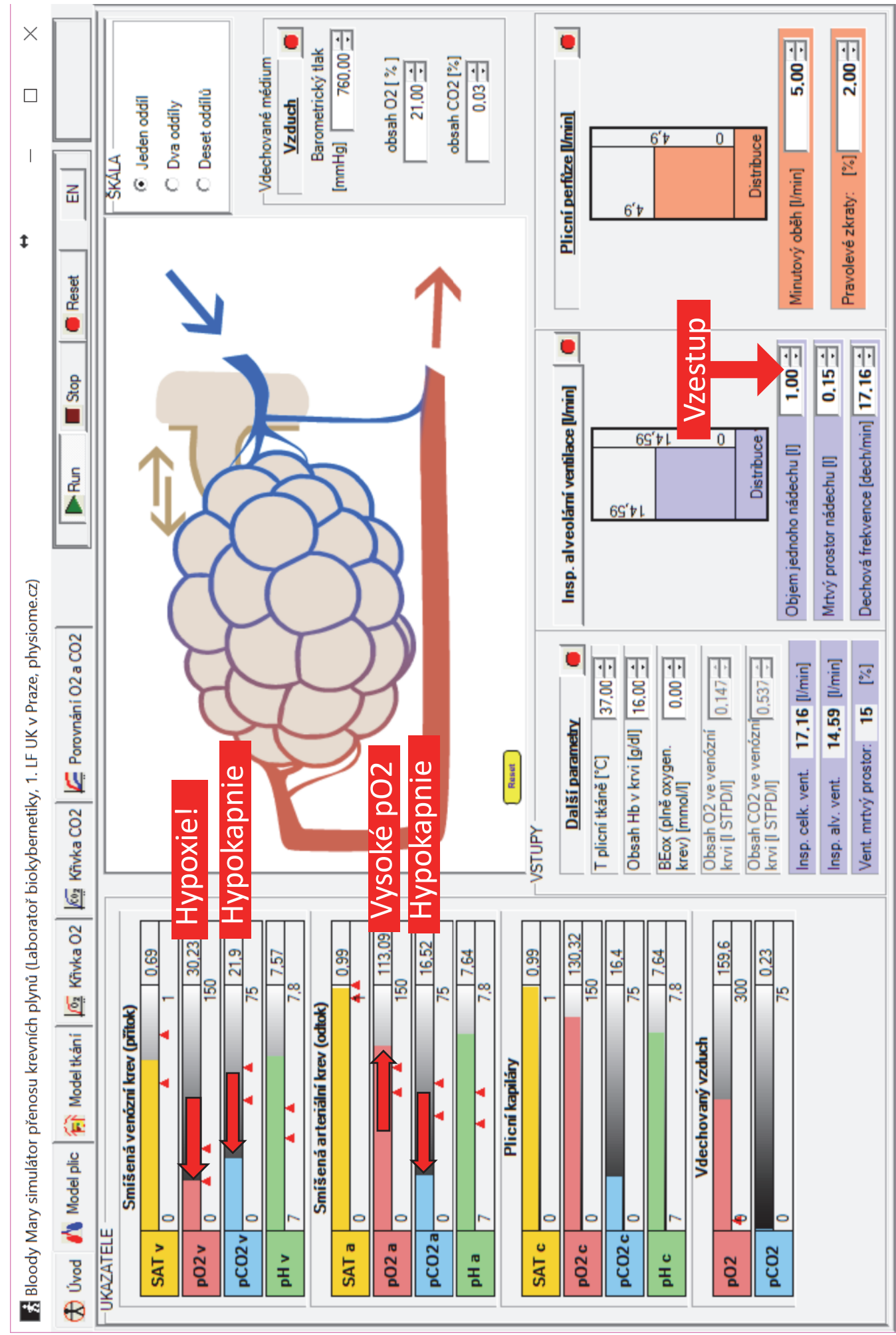

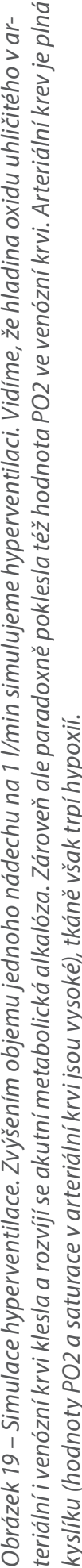

\section{Krevní plyny a poruchy respirace}

Přenos krevních plynů závisí nejen na cirkulaci, ale i na respiraci (proto se ve fyziologii hovoří o kardiorespiračním systému). To, že snížení ventilace vede $\mathrm{k}$ poklesu $\mathrm{PaO} 2 \mathrm{a} \mathrm{CaO} 2$ a následně ke snížení dodávky kyslíku do tkání a tkáňové hypoxii je pochopitelné. Poněkud překvapivé ale na první pohled může být, že hyperventilace zpočátku sníží PO2 v tkáních. Na modelu si to můžeme nasimulovat náhlým zvýšením ventilace (imitujícím situaci, kdy na přístroji pro umělou plicní ventilaci nastavíme príliš vysokou hodnotu ventilace a pacienta "převentilujeme") - Obr. 16. V arteriální krvi vidíme vzestup hodnoty PO2, avšak hladina PO2 ve venózní krvi, která je ekvilibrována s hladinou 

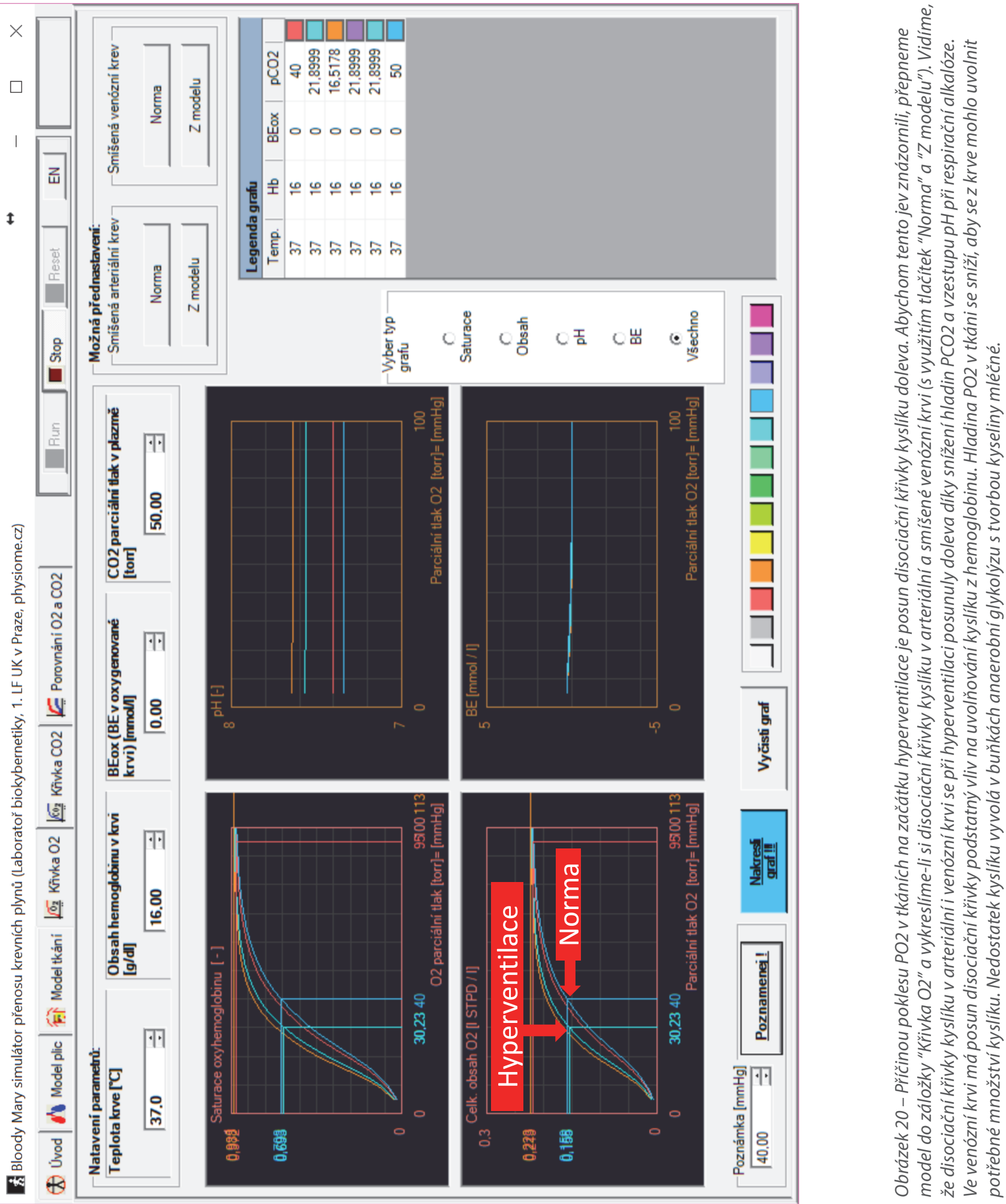

PO2 v tkáních, se sníží - arteriální krev je plná kyslíku ale tkáně trpí hypoxií. Abychom objasnili tento zdánlivě paradoxní děj, musíme se podívat na disociační křivku kyslíku - Obr. 20. Akutní respirační alkalóza posouvá disociační křivku kyslíku doprava. Aby se z hemoglobinu odvázalo potřebné množství kyslíku při nezměněné spotřebě kyslíku, hladina PO2 se sníží. Snížení hladiny PO2 v buňkách ale vyvolá tvorbu kyseliny mléčné, která posune $\mathrm{pH} z$ alkalické strany zpět směrem k normálnímu $\mathrm{pH}$, což vede $\mathrm{k}$ posunu disociační křivky kyslíku směrem doprava a k následnému vzestupu PO2. Můžeme si to ukázat na modelu (viz Obr. 21). Laktátová acidóza způsobí pokles hodnoty Base Excess (BE). Později je snížení BE způsobeno metabolickou od- 

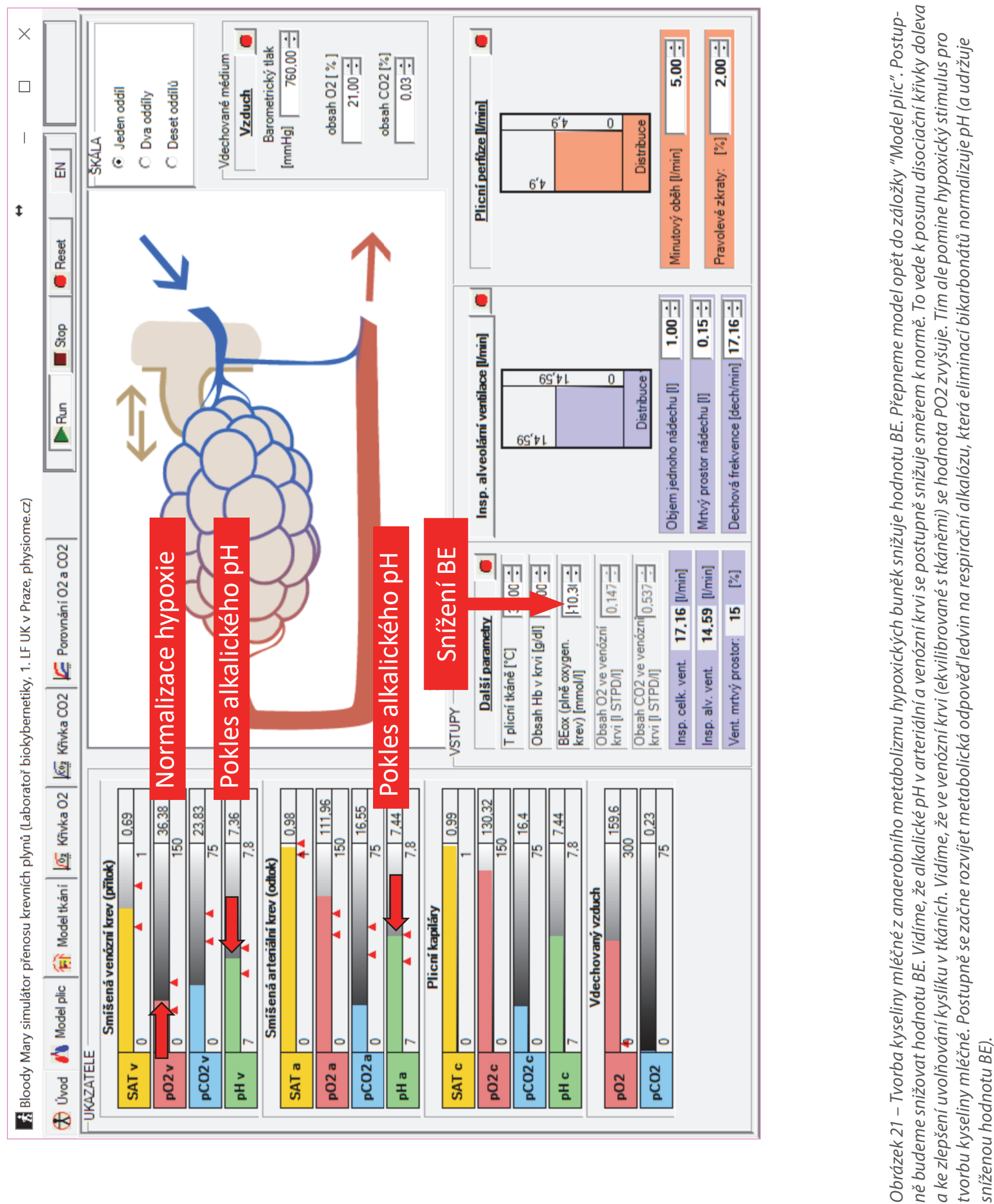

povědí ledvin na respirační alkalózu, která se rozvíjí během 3-5 dní. Snižujeme-li na modelu hodnotu BE, pozorujeme postupný pokles $\mathrm{pH}$ a vzestup hladiny $\mathrm{PO} 2$ ve venózní krvi, odtékající z tkání.

Interaktivní model umožní také názorně vysvětlit příčiny změn hladin krevních plynů v arteriální krvi při poruchách ven- tilace a při narušení poměru ventilace-perfúze. Při emfyzému se zvětšuje mrtvý prostor na úkor alveolární ventilace, což vede k vzestupu PaCO2 a poklesu PaO2 (viz Obr. 22). Dechové centrum zvýší celkovou ventilaci a normalizuje hladiny arteriálních krevních plynů za cenu zvýšeného dechového úsilí (viz Obr. 23). Proto pacienti s emfyzémem mají normální hladiny jak kyslíku, 


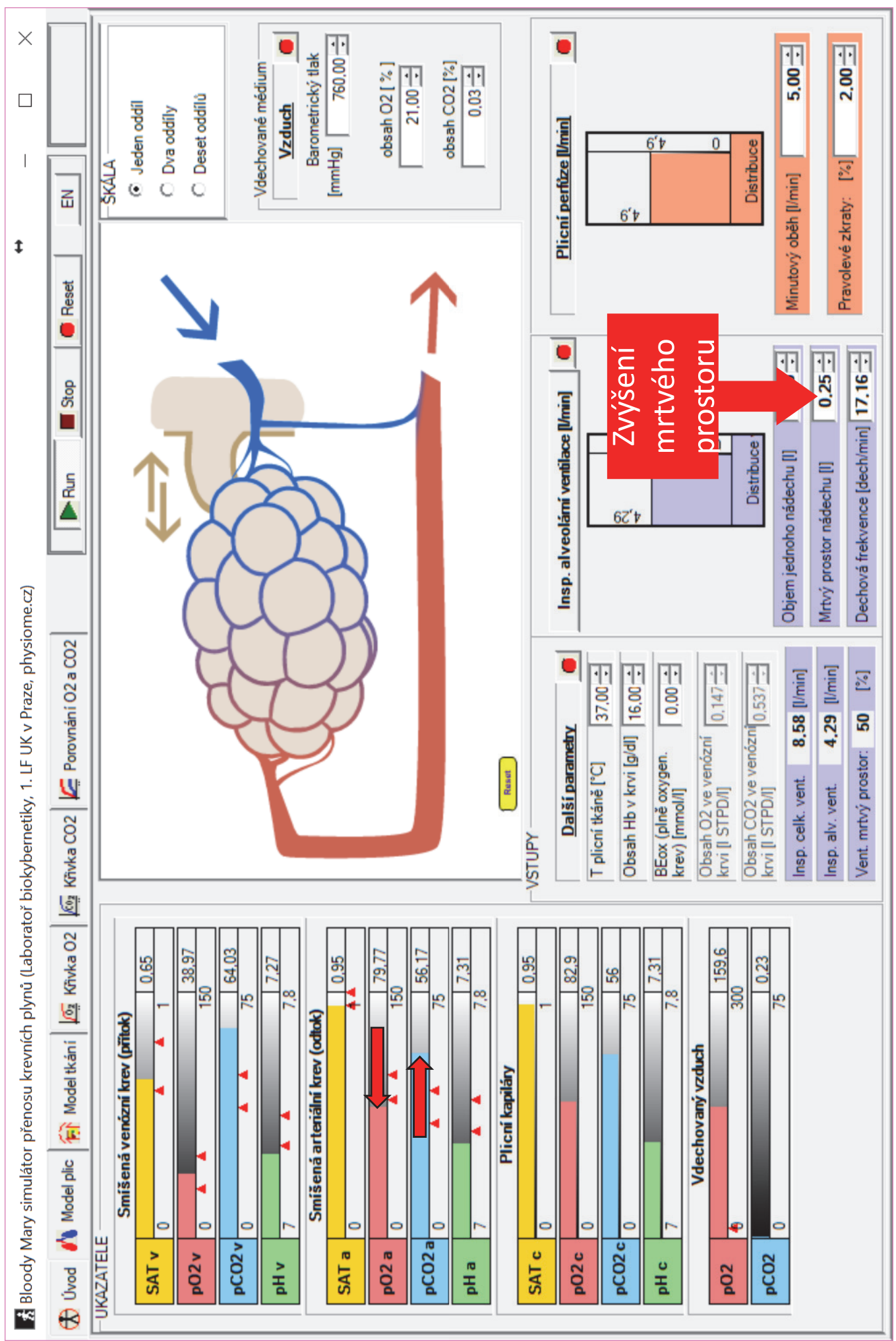

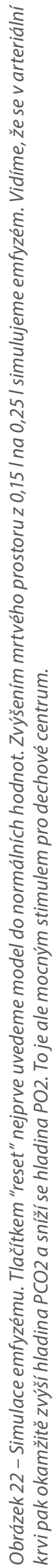




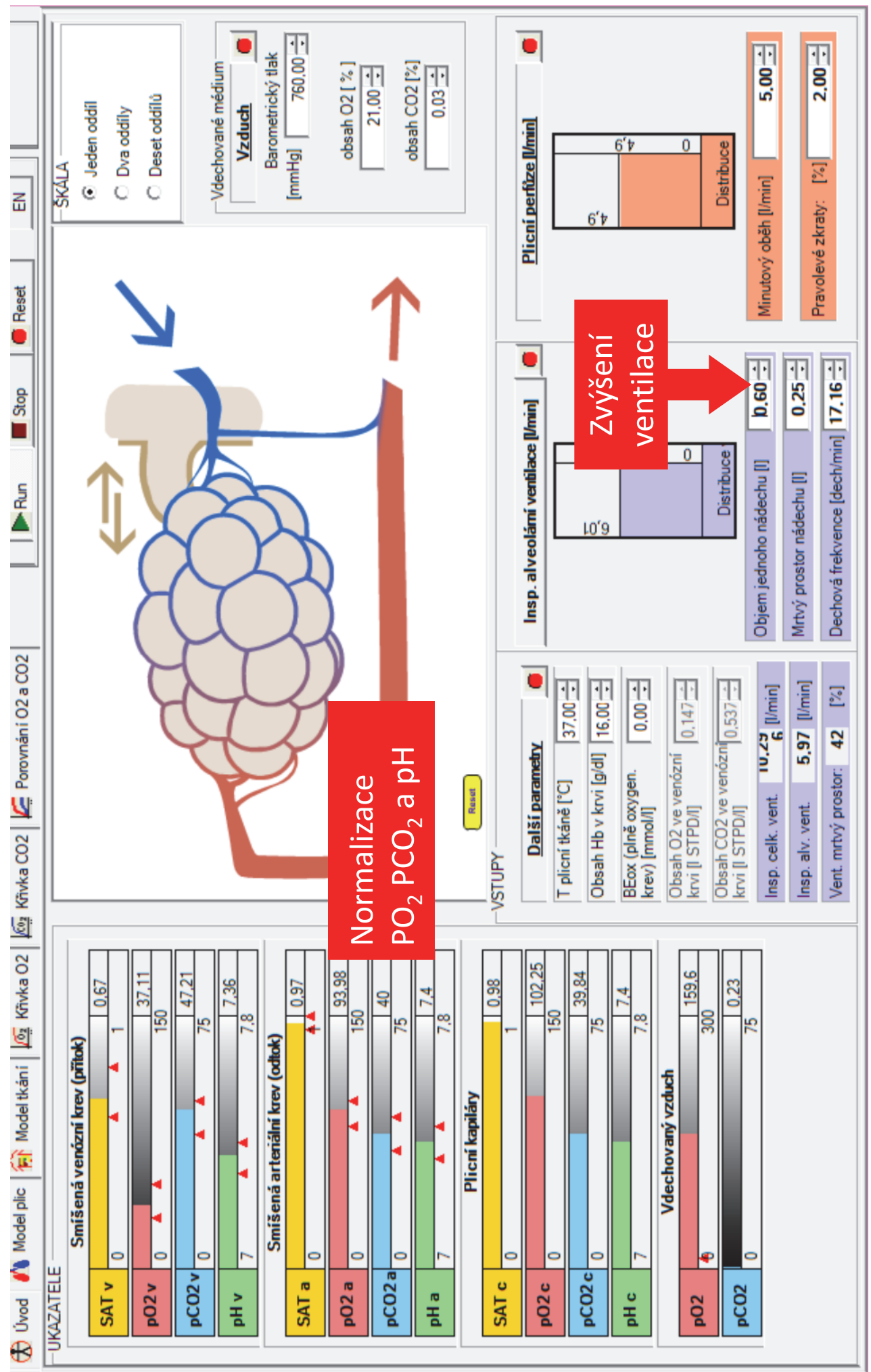

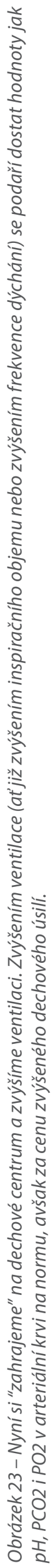



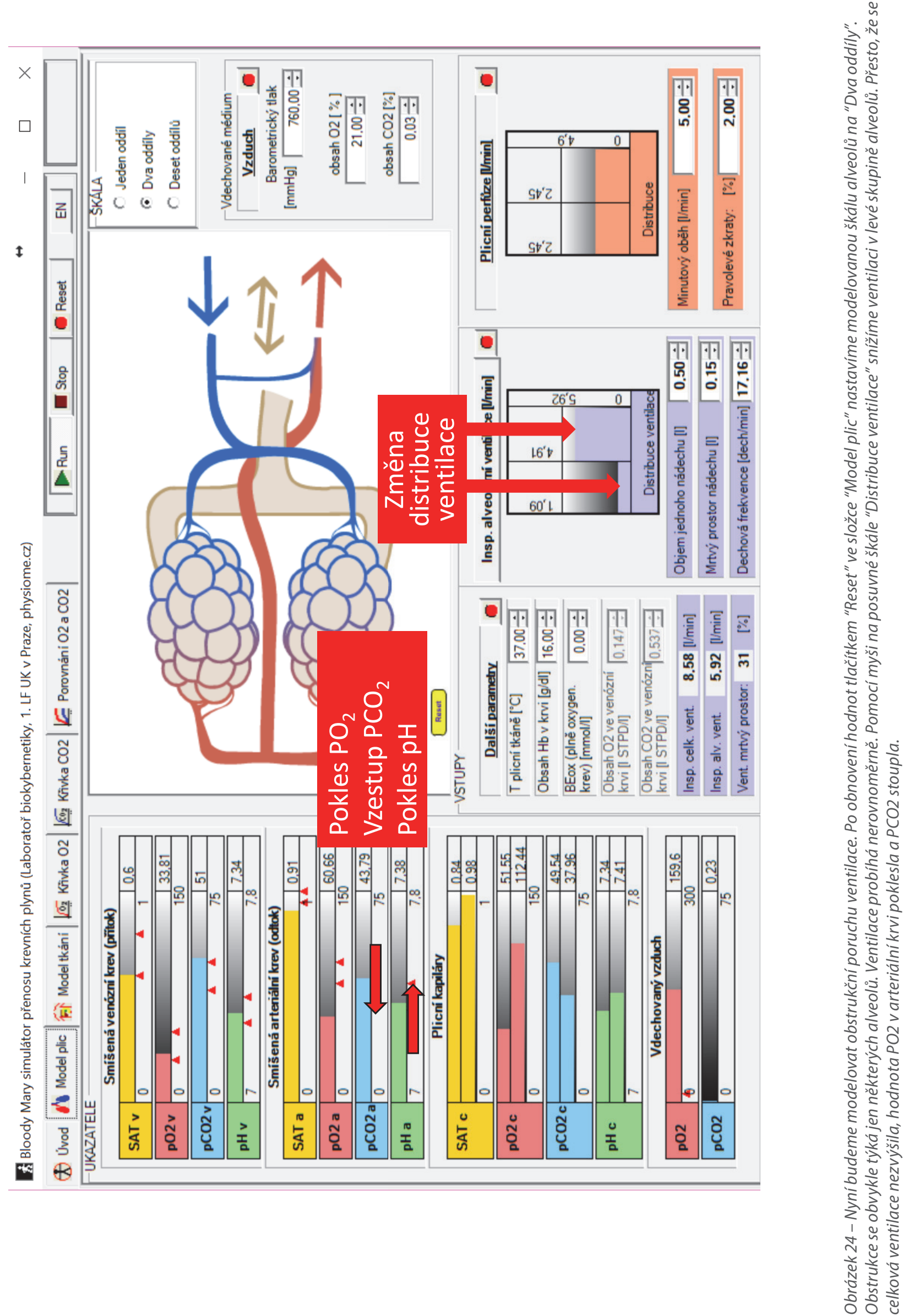


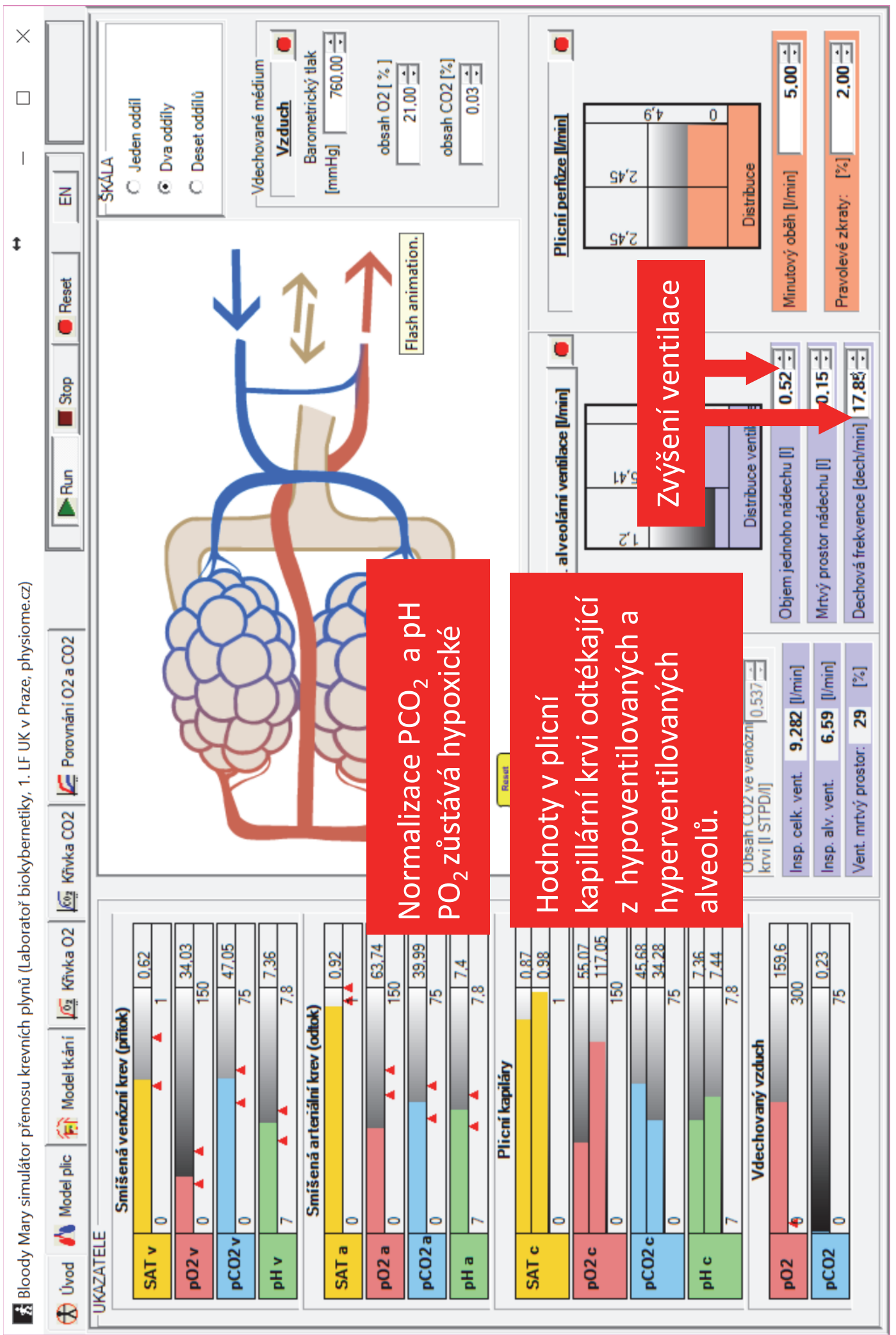

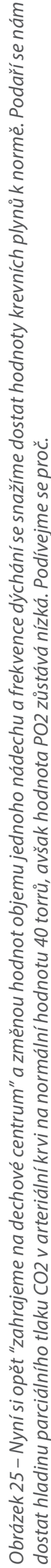



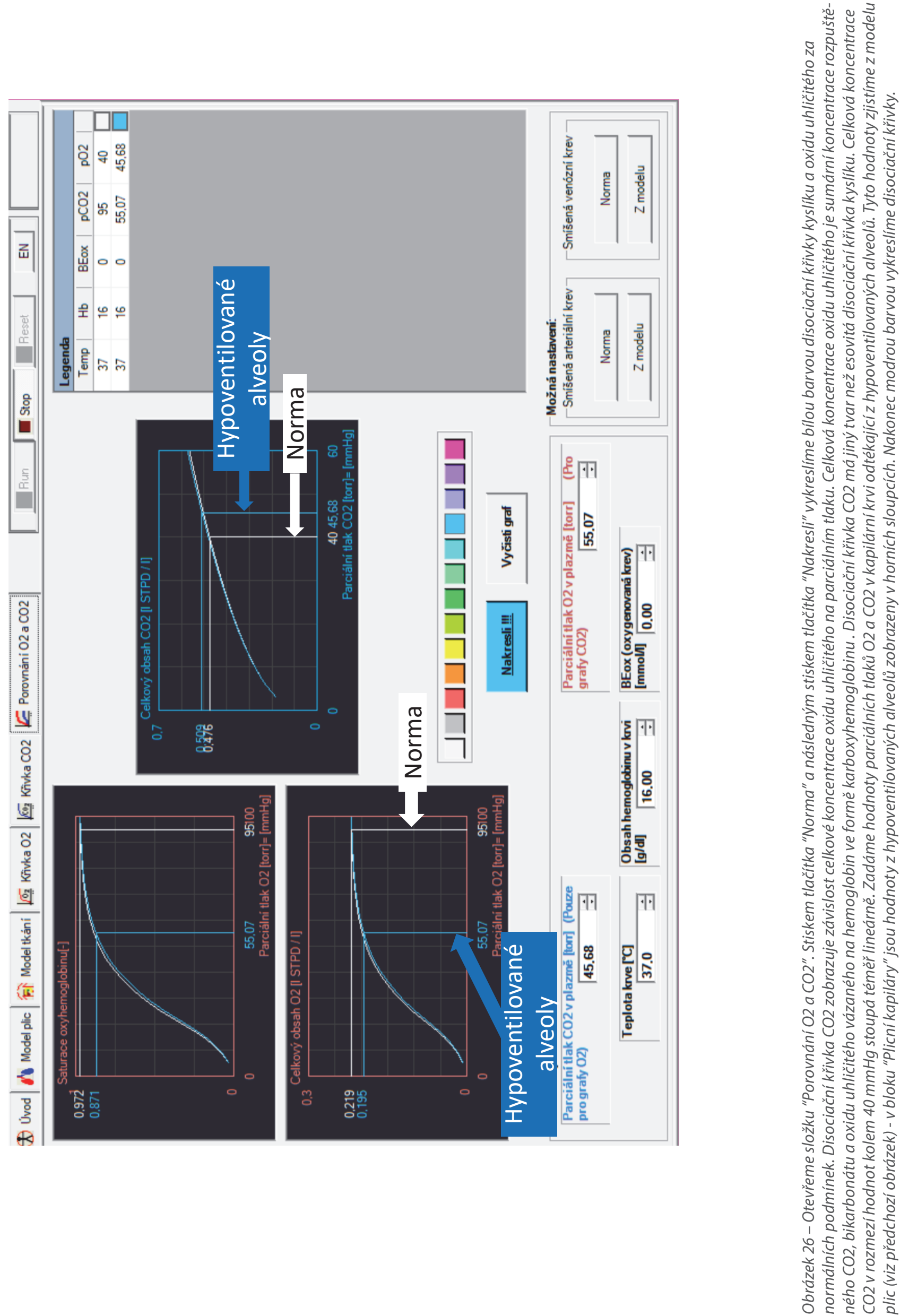

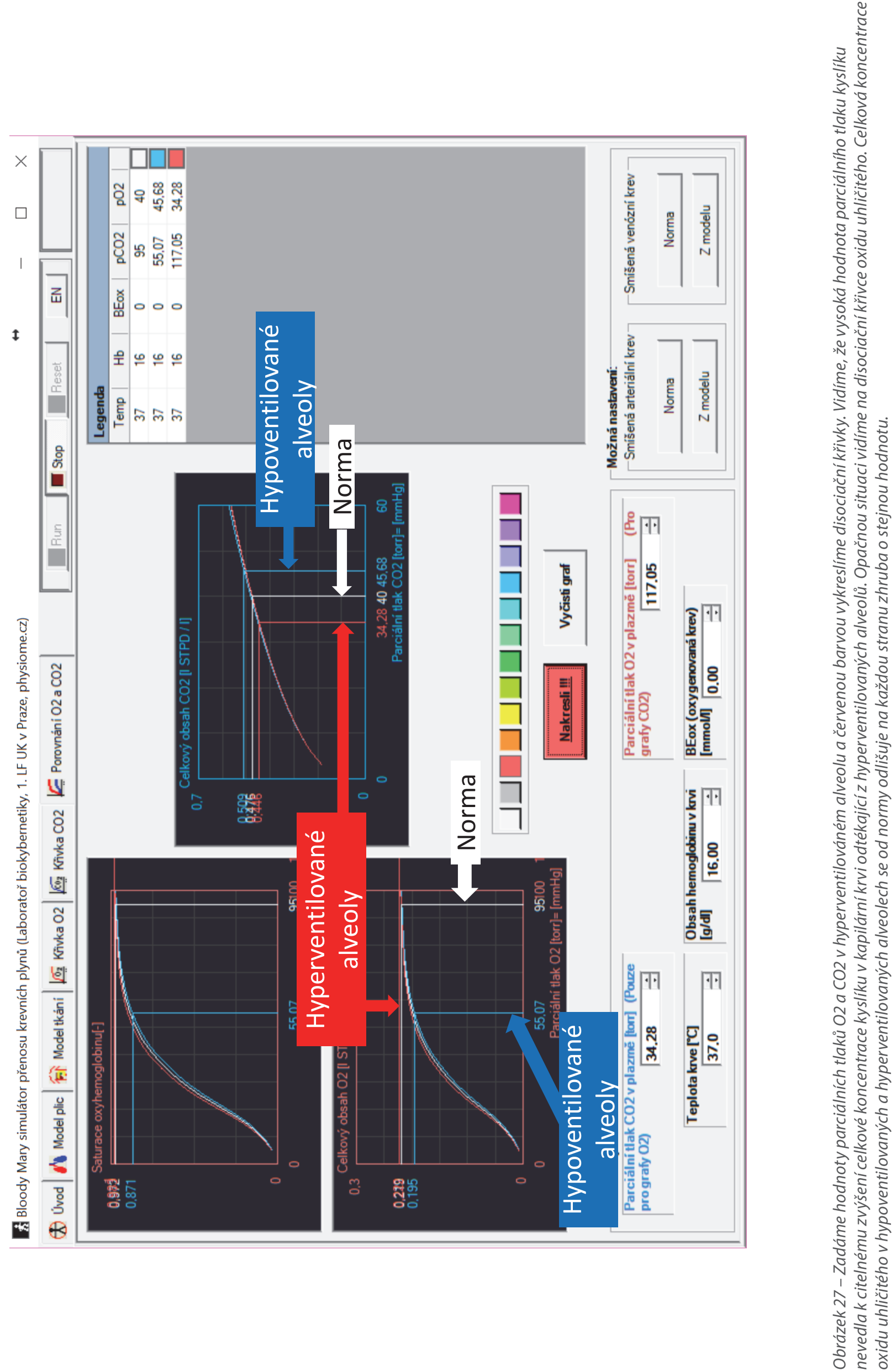

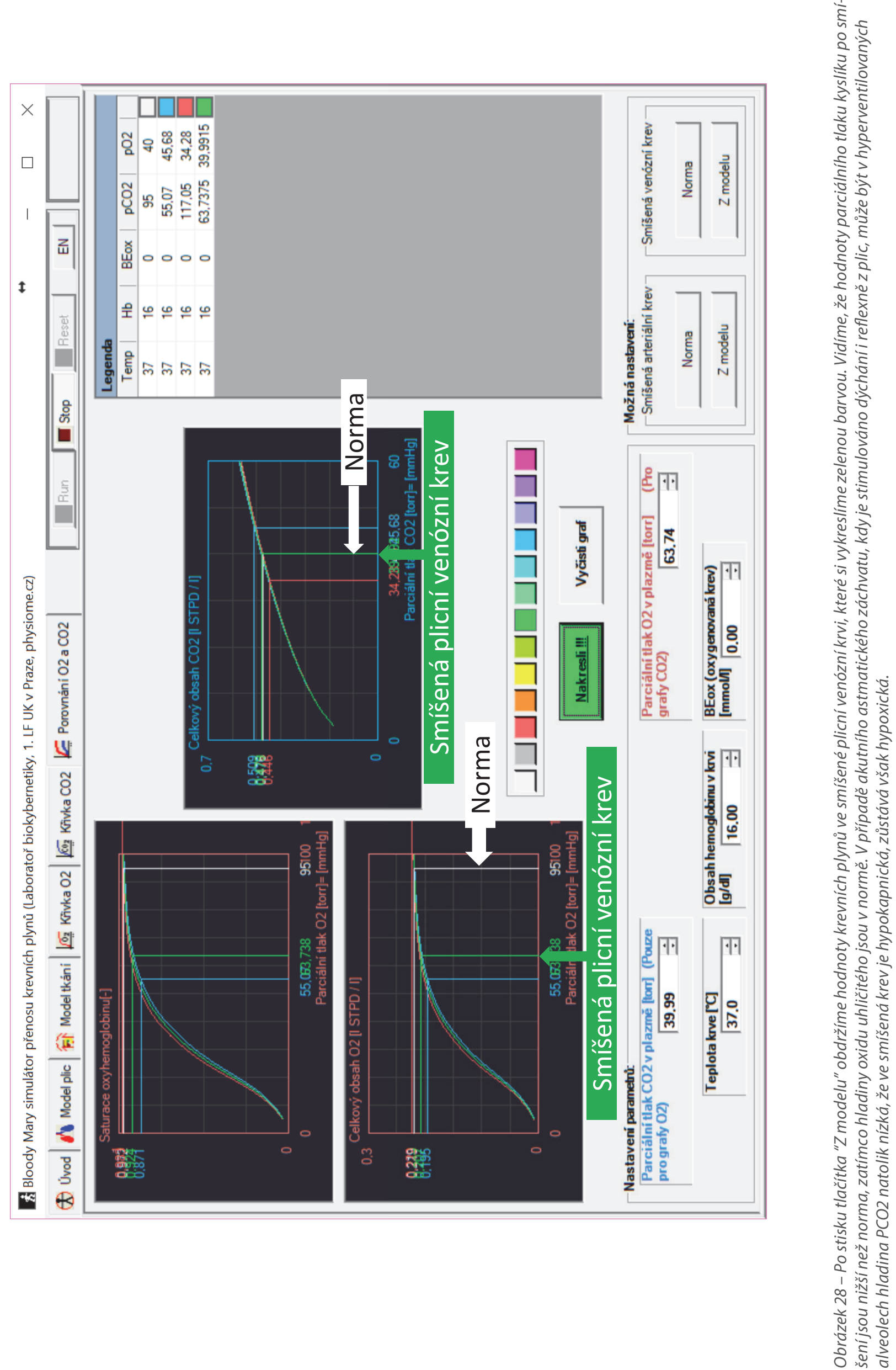

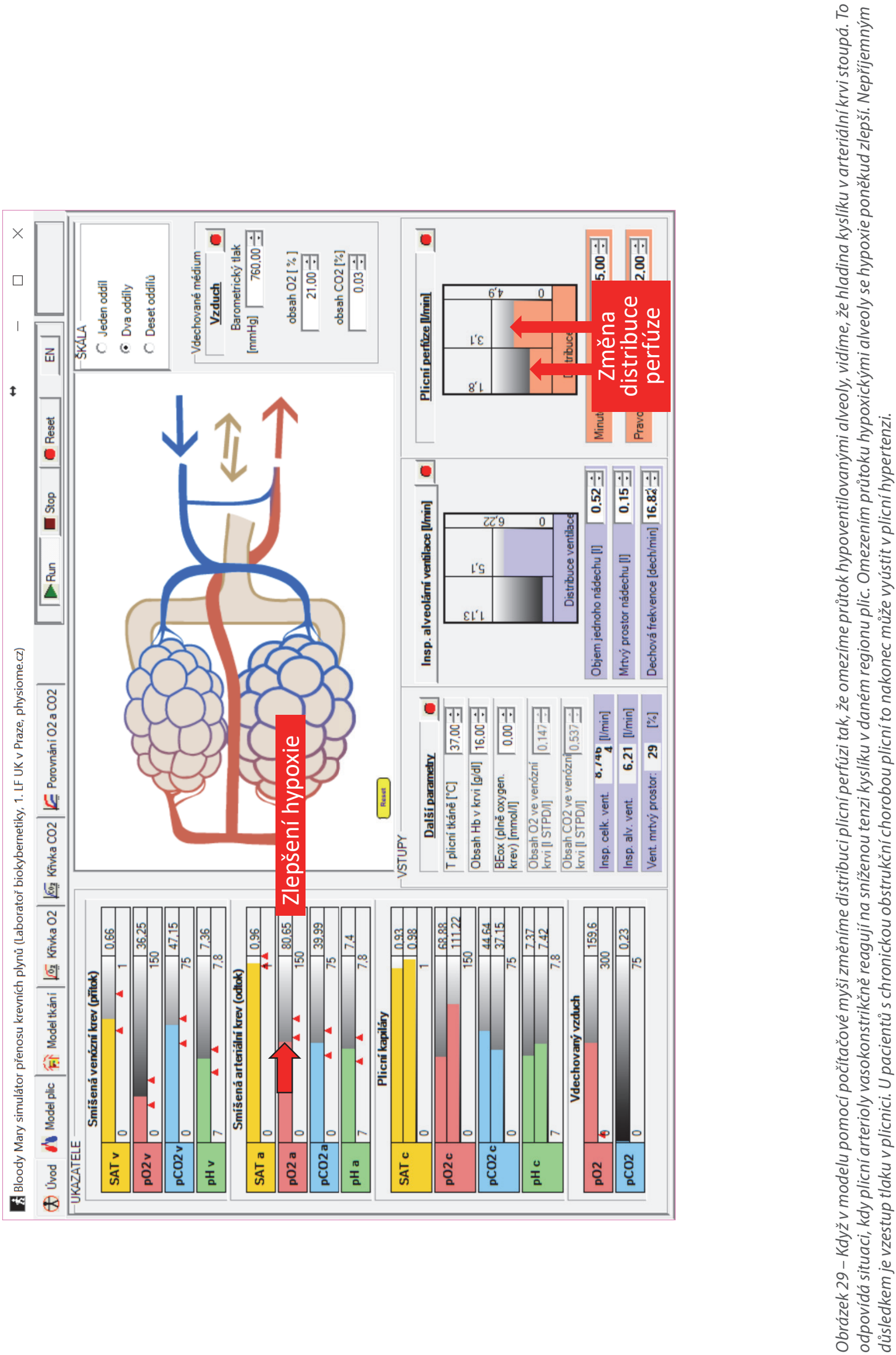


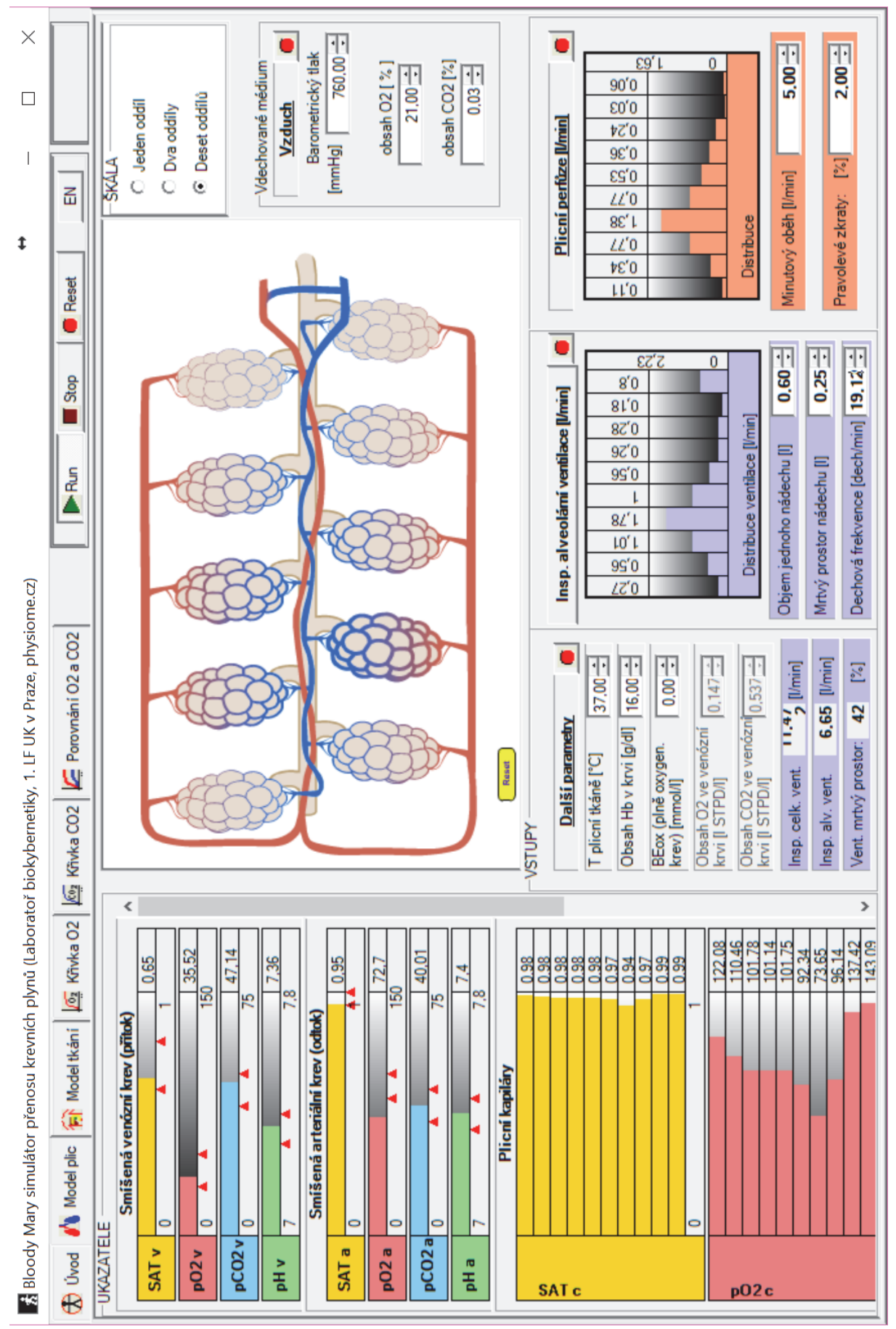

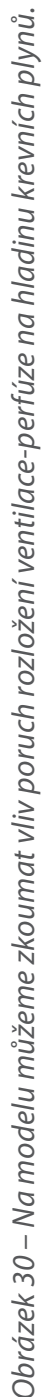


tak i oxidu uhličitého při velkém subjektivním pocitu dušnosti.

Na rozdíl od emfysematických pacientů, mají pacienti s plicní obstrukcí hladinu kyslíku v arteriální krvi sníženou. Hladina oxidu uhličitého $v$ arteriální krvi je normální, nebo je dokonce (při akutním astmatickém záchvatu) snížená. Sníženou hladina kyslíku při normální hladině oxidu uhličitého pozorujeme také u pacientů s poruchami plicní difúze (např. při plicních fibrózách). Protože oxid uhličitý je zhruba dvacetinásobně rozpustnější než kyslík, u pacientů s poruchami plicní difúze se krev v plicních kapilárách stačí ekvilibrovat s hladinou $\mathrm{CO} 2$ v alveolárním vzduchu, zatímco s kyslíkem se ekvilibrovat nestačí a hladina PO2 v arteriální krvi je proto snížená. U pacientů s plicní obstrukcí vysvětlení př́čin snížení arteriálního $\mathrm{PO} 2$ při normální (nebo dokonce snížené) hladině PCO2 spočívá v rozdílnosti tvaru disociačních křivek kyslíku a oxidu uhličitého v krvi. K pochopení patogeneze tohoto poměrně spletitého děje pomůže interaktivní model (viz Obr. 24-29).

Na modelu přenosu krevních plynů můžeme názorně demonstrovat vliv distribuce ventilace-perfúze na hladiny krevních plynů (Obr. 30) nebo vliv distribuce perfúze $v$ různých částech tkání na hladiny krevních plynů ve venózní krvi. Hrou s výukovým modelem můžeme studovat i další patogenetické mechanismy kardiorespiračních poruch, např. výškovou hypoxii nebo vliv zvýšeného barometrického tlaku při potápění nebo $v$ barokomoře aj.

\section{Uplatnění ve výuce}

Výše uvedené výukové modely cirkulace a přenosu krevních plynů využíváme ve výuce patologické fyziologie. Hrám se simulačním modelem cirkulace a respirace byl věnován dvouhodinový seminár jak v zimním, tak i v letním semestru. Hry se simulačními modely oproti klasické výuce vedly k lepšímu pochopení vzájemných dynamických souvislostí při cirkulačních a respiračních poruchách, model cirkulace přispěl především k pochopení základních patogenetických mechanismů rozvoje srdečního selhání, vztahu regulace objemu a cirkulace. Hry s modelem výměny krevních plynů především přispěly k pochopení mechanismu ventilačně perfúzních poruch.

Naše zkušenost $s$ uplatněním simulačních her ve výuce ukazuje, že jednoduché a přehledné modely bez implementovaných fyziologických regulací mají význam pro pochopení základních vztahů ve studovaném fyziologickém subsystému. Tím, že v simulačních experimentech můžeme experimentovat s jednotlivými proměnnými, které jsou ve fyziologickém systému regulované, můžeme význam těchto regulací lépe pochopit.

Pro pedagogický dopad má význam i způsob prezentace interaktivní animované obrázky řízené modelem mají pro pochopení větší význam než pouhá sada křivek průběhů jednotlivých proměnných.

I sebepřehlednější model však ztrácí svou pedagogickou hodnotu, pokud není prezentován ve výuce pedagogem, který je v interakci se studenty schopen pomocí modelu vysvětlit složitou látku. Dokonce by se dalo říci, že uplatnění simulátorů ve výuce klade větší nároky na učitele než klasická výuka.

Budoucnost mají modely propojené s výkladem ve formě interaktivní učebnice. Díky mobilním technologiím a rozvoji tabletů totiž vzniká nový druh učebnic - do elektronické formy převedené tištěné učebnice. Tak např. Daniel Burkhoff vydal učebnici kardiovaskulární fyziologie a patofyziologie určenou pro tablety firmy Apple (Doshi, 2016 Leisman 2017), kde se snoubí text, interaktivní animace řízená modelem a velký kardiovaskulární model http://www.pvloops.com.

\section{Poděkování}

Výukové modely cirkulace a přenosu krevních plynů jsou výsledkem grantového projektu Univerzity Karlovy GAUK č.
198416 a jsou v české a anglické verzi volně přístupné na adrese www.physiome.cz/atlas.

\section{Literatura}

[1.] Guyton AC, Coleman TG, Granger HJ. Circulation: overall regulation. Annu Rev Physiol. annualreviews.org; 1972;34: 13-46.

[2.] Coleman TG, Randall JE. HUMAN. A comprehensive physiological model. Physiologist. Citeseer; 1983;26: 15-21.

[3.] Abram SR, Hodnett BL, Summers RL, Coleman TG, Hester RL. Quantitative Circulatory Physiology: an integrative mathematical model of human physiology for medical education. Adv Physiol Educ. Am Physiological Soc; 2007;31: 202-210.

[4.] Hester R, Brown A, Husband L, Iliescu R. HumMod: a modeling environment for the simulation of integrative human physiology. Frontiers in Physiology. journal.frontiersin.org; 2011; Available: http:// journal.frontiersin.org/article/10.3389/fphys.2011.00012

[5.] Xu L, Lyle J, Wu Y, Pan Z, Zhang M, Laidlaw DH, et al. HumMod Explorer: A Multi-scale Time-varying Human Modeling Navigator. SIGGRAPH Asia 2011 Posters. New York, NY, USA: ACM; 2011. pp. 28:1-28:1.

[6.] Hester RL, Iliescu R, Summers R, Coleman TG. Systems biology and integrative physiological modelling. J Physiol. Wiley Online Library; 2011;589: 1053-1060.

[7.] Wu K, Chen J, Pruett WA, Hester RL. Hummod browser: An exploratory visualization tool for the analysis of whole-body physiology simulation data. 2013 IEEE Symposium on Biological Data Visualization (BioVis). ieeexplore.ieee.org; 2013. pp. 97-104.

[8.] Chen J, Wu K, Pruett WA, Hester RL. HumMod browser: An exploratory visualization tool for model validation of whole-body physiology simulation. Eurographics Conference on Visualization (EuroVis)(short paper). researchgate.net; 2013. Available: https://www.researchgate. net/profile/Keqin Wu2/publication/303290077 HumMod Browser An Exploratory Visualization Tool for Model Validation of Whole-Body Physiology Simulation/links/573f6ab108ae298602e8f3cf.pdf

[9.] Pruett $W$, Husband $L$, Hester $R$. Understanding variation in salt sensitivity in HumMod, a human physiological simulator (857.11). The FASEB Journal. 2014;28. Available: http://www.fasebj.org/content/28/1 Supplement/857.11.abstract

[10.] Lerant AA, Hester RL, Coleman TG, Phillips WJ, Orledge JD, Murray WB. Preventing and Treating Hypoxia: Using a Physiology Simulator to Demonstrate the Value of Pre-Oxygenation and the Futility of Hyperventilation. Int J Med Sci. ncbi.nIm.nih.gov; 2015;12: 625-632.

[11.] Clemmer JS, Pruett WA, Coleman TG, Hall JE, Hester RL. Mechanisms of blood pressure salt sensitivity: new insights from mathematical modeling. Am J Physiol Regul Integr Comp Physiol. Am Physiological Soc; 2016;312: R451-R466.

[12.] Pruett WA, Clemmer JS, Hester RL. Validation of an integrative mathematical model of dehydration and rehydration in virtual humans. Physiol Rep. 2016;4: 1-20.

[13.] Blair ET, Clemmer JS, Harkey HL, Hester RL, Pruett WA. Physiological Mechanisms of Water and Electrolyte Disturbances Following Transsphenoidal Pituitary Surgery. World Neurosurg. Elsevier; 2017;104: 429-436.

[14.] Comenius JA. Schola ludus seu Encyclopaedea Viva. Sarospartak; 1656.

[15.] Kofránek J, Matoušek S, Andrlik M, Stodulka P, Wünsch Z, Privitzer P, et al. Atlas of physiology-internet simulation playground. Proceedings of the 6th EUROSIM Congress on Modeling and Simulation. 2007. pp. 1-9.

[16.] Kofránek J, Privitzer P, Matoušek S, Mateják M, Vacek O, Tribula M, et al. Schola Ludus in Modern Garment: Use of Web Multimedia Simu- 
Iation in Biomedical Teaching. IFAC Proceedings Volumes. Elsevier; 2009;42: 413-418.

[17.] Kofránek J, Matoušek S, Rusz J, Stodulka P, Privitzer P, Mateják M, et al. The Atlas of Physiology and Pathophysiology: Web-based multimedia enabled interactive simulations. Comput Methods Programs Biomed. 2011;104: 143-153.

[18.] Elmqvist H, Mattsson SE. An introduction to the physical modeling language Modelica. Proceedings of the 9th European Simulation Symposium, ESS. 1997. pp. 19-23.

[19.] Fritzson P, Engelson V. Modelica-A unified object-oriented language for system modeling and simulation. European Conference on Object-Oriented Programming. Springer; 1998. pp. 67-90.

[20.] Elmqvist H, Mattsson SE, Otter M. Modelica: The new object-oriented modeling language. 12th European Simulation Multiconference, Manchester, UK. 1998. Available: http://www.academia.edu/download/31411522/esm98mod.pdf

[21.] Elmqvist H, Mattsson SE, Otter M. Modelica-a language for physical system modeling, visualization and interaction. Proceedings of the 1999 IEEE International Symposium on Computer Aided Control System Design (Cat No99TH8404). ieeexplore.ieee.org; 1999. pp. 630-639.

[22.] Fritzson P. Introduction to modeling and simulation of technical and physical systems with Modelica. John Wiley \& Sons; 2011.

[23.] Fritzson P. Principles of object-oriented modeling and simulation with Modelica 3.3: A cyber-physical approach. John Wiley \& Sons; 2014.

[24.] Tiller M. Introduction to physical modeling with Modelica. Springer Science \& Business Media; 2012.

[25.] Tiller M. Modelica by Example - electronic interactive book: http:// book. xogeny. com. Xogeny.com; 2014.

[26.] Kofránek J, Mateják M, Privitzer P. Leaving toil to machines-building simulation kernel of educational software in modern software environments. Mefanet 2009. mefanet.cz; 2009; Available: http://www. mefanet.cz/res/file/mefanet2009/prispevky/kofranek_full.pdf

[27.] Kulhánek T, Kofránek J, Mateják M. Modeling of short-term mechanism of arterial pressure control in the cardiovascular system: object-oriented and acausal approach. Comput Biol Med. 2014;54: 137-144.

[28.] Ježek F, Kulhánek T, Kalecký K, Kofránek J. Lumped models of the cardiovascular system of various complexity. Biocybernetics and Biomedical Engineering. Elsevier; 2017;37: 666-678.

[29.] Mateják M. Formalization of Integrative Physiology. Charles University in Prague [Internet]. Kofránek J, editor. Ph.D., Charles University. 2015. Available: https://github.com/MarekMatejak/dissertation/ blob/master/thesis.pdf

[30.] Mateják M, Kofránek J. Physiomodel - an integrative physiology in Modelica. 2015 37th Annual International Conference of the IEEE Engineering in Medicine and Biology Society (EMBC). 2015. pp. 1464-1467.

[31.] Kofránek J, Kulhánek T, Mateják M, Ježek F, Šilar J. Integrative physiology in Modelica. In: Kofránek J, Casella F, editors. Proceedings of the 12th International Modelica Conference. Linköping, Sweden: Modelica Association and Linköping University Electronic Press; 2017. pp. 589-603.

[32.] Silbernag/ S, Despopoulos A. Color atlas of physiology. Thieme; 2009

[33.] SilbernagI S, Lang F. Color atlas of pathophysiology. Thieme; 2010.

[34.] Privitzer P, Šilar J, Kulhánek T, Mateják M, Kofránek J. Simulation Applications in Medical Education. In: J M, Hasman A, Zvárová J, editors. Proceedings of the EFMI Special Topic Conference, WS1 workshop (CD ROM Proceedings). European Federation of Medical Informatics and IOS Press; 2013. pp. 1-5.
[35.] Kofránek J, Mateják M, Privitzer P. Web simulator creation technology. MEFANET report. 2010;3: 32-97.

[36.] Tribula M, Ježek F, Privitzer P, Kofránek J, Kolman J. Webový výukový simulátor krevního oběhu. sborník přispěvkŭ MEDSOFT. creativeconnections.cz; 2013;25: 197-204.

[37.] van Dam PM, Oostendorp TF, van Oosterom A. ECGSIM: Interactive simulation of the ECG for teaching and research purposes. 2010 Computing in Cardiology. ieeexplore.ieee.org; 2010. pp. 841-844.

[38.] umens J. Creating your own virtual patient with CircAdapt Simulator. Eur Heart J. ncbi.nlm.nih.gov; 2014;35: 335-337.

\section{Kontakt}

\section{Jiří Kofránek}

Oddělení biokybernetiky a počítačové podpory výuky ÚPF 1. LF UK,

Praha U Nemocnice 5128 53,

Praha 2

email. kofranek@gmail.com 